\title{
Leydis, Pauli, and Berchen Revisited Collective History Writing in the Low Countries in the Late Fifteenth Century*
}

\author{
Rombert Stapel \& Jenine De VRIES \\ International Institute of Social History \& Durham University
}

\begin{abstract}
This article focuses on a generation of chroniclers from the Low Countries operating at the intersection of urban and clerical environments and how they worked together to produce new historiographical texts. At the heart are the writings of three of the most productive and well-known historiographers of this generation: Johannes a Leydis, Theodericus Pauli and Willem van Berchen. The interdependency of a specificpart of their body of work, namely their Chronicles of Holland, will be studied closely. This will lead to a new proposal for the complex relationship between these and other related contemporary texts. From this the contours emerge of a community of writers, reaching much further than these three alone, which shared a common interest in historiography and exchanged texts, ideas and manuscripts. In each of their texts, the influence of this exchange is tangible, exhibiting the collaborative nature of their historical writings, rarely detected in the Middle Ages.
\end{abstract}

\section{Introduction}

History writing can be a lonely profession. The image comes to mind of a secluded writer, alone with only a library and a pen, working through a new creation. Medieval portrayals of writers almost always reinforce this notion. If one googles pictures of 'medieval writer' or 'medieval scribe', a vast array of analogous miniatures emerges of individuals sitting alone

We would like to thank our colleagues at both Leiden University and Durham University, in particular Hans Mol, Robert Stein, and Graeme Small, as well as the anonymous reviewers for their help in improving earlier drafts of this paper. 
on a chair, bent over their vellum whilst writing. ${ }^{.}$While this stereotype might hold some truth, it can be questioned how solitary the writing process really was. For instance, many medieval authors dictated their text and employed scribes to do the actual writing. ${ }^{2}$ At the same time, and especially in the genre of historiography, a strict distinction between authors and scribes, authors and readers, cannot always be made. The specific nature of history writing invited its readership, often first and foremost scribes who handled the manuscripts, to participate in, enhance, and rewrite the texts. ${ }^{3}$

In this article we will discuss the collective nature of history writing in the Late Middle Ages by examining a specific case in and around the County of Holland. For the Duchy of Brabant, Robert Stein has discussed one example of such collaboration. He has shown how three individuals worked together on the so-called Continuation of Jan van Boendale's Brabantsche Yeesten, a rhymed chronicle in Middle Dutch on the history of the duchy. Stein describes how the pensionary of the city of Brussels, Petrus de Thimo, ducal secretary at the Burgundian court Emond de Dynter and an anonymous poet later identified as Wein van Cotthem, ${ }^{4}$ worked together to create the Continuation.5 Stein refers to Thimo as the 'master builder'. An overseer who collected the material, with help of Dynter, the 'supplier of building materials', and who directed Cotthem, the 'builder', to create a rhymed text. ${ }^{6}$ Not only was the Continuation

See also: K. Giogoli, 'Author portraits', in G. Dunphy (ed.), Encyclopedia of the Medieval Chronicle (Leiden/Boston, 2010), pp. I29-133; M. Fisher, Scribal Authorship and the Writing of History in Medieval England (Columbus, 2012), p. 3.

2 A. Houthuys, Middeleeuws kladwerk. De autograaf van de Brabantsche yeesten, boek VI (vijftiende eeuw) (Schrift en Schriftdragers in de Nederlanden in de Middeleeuwen, IV) (Hilversum, 2009), pp. 8I-86.

3 Fisher, Scribal Authorship, p. 6; See also: S. Kelly and J.J. Thompson, 'Imagined Histories of the Book. Current Paradigms and Future Directions', in id. and id. (eds), Imagining the Book (Medieval Texts and Cultures of Northern Europe, 7) (Turnhout, 2005), pp. I-I4 (spec. p. 9); D. Hobbins, Authorship and Publicity Before Print. Jean Gerson and the Transformation of Late Medieval Learning (Philadelphia, 2009), pp. 154-156.

4 Houthuys, Middeleeuws kladwerk, p. 47.

5 R. Stein, Politiek en historiografie. Het ontstaansmilieu van Brabantse kronieken in de eerste helft van de vijftiende eeuw (Miscellanea neerlandica, IO) (Leuven, 1994).

$6 \quad$ Ibid., p. 57. 
affected by the collaboration between these three, but other works by Thimo and Dynter were closely interrelated too.?

A definition of 'collaborative' or 'collective' writing is not easy to produce. ${ }^{8}$ A narrow definition that focusses on a formal shared responsibility (or shared authorship) over the document would exclude most of the examples given below, if not all instances of collaborative writing in the Middle Ages. Nor do we wish to suggest here that every chronicle that incorporates the work of others, especially the genre of historiographical texts referred to by Matthew Fisher as 'derivative texts' that seldom credit their sources, is somehow a collaborative product. ${ }^{9}$ In a strict sense, this also applies to various continuations of chronicles, their conception sometimes spanning decades or even centuries, but which are nonetheless sometimes referred to as 'collaborative efforts. ${ }^{10}$ Gérard Genette's notion of réécriture provides relaxation over this rewriting and fluency of medieval manuscripts. ${ }^{11}$ It gives us the possibility to study a text without the need for one 'true' copy of the text, but taking each version with its own details, dialects, and emphasises at its own value. Although we attempt a detailed look at the order of manuscripts and different passages in the texts, this article does not attempt to establish a 'real' text of any of those chronicles. The manuscripts are the only physical legacy of the interaction between authors, and detailed study of them is the only way to unfold the level and nature of interaction between Holland's historiographers. However, rewriting or writing continuations do not $a$ priori imply that there was some human interaction between the authors that led to the creation of the text, except, of course, in a unilateral manner via the text itself.

It is this interaction, the human interaction and mutual exchange between two or more individuals, specifically with the intention to create new (historiographical) texts, that we will focus on in this article. Prerequisites for such interactions are that the writers are contemporaries, who may or may not work in the same environment, but who stood in

Ibid., passim, e.g. p. 304 .

8 For a discussion of the definitions and various coexisting modes of collaborative writing: L.S. Ede and A.A. Lunsford, Singular texts/plural authors. Perspectives on collaborative writing (Carbondale, 1990), pp. 14-16, 133-136.

9 Fisher, Scribal Authorship, p. 60.

10 e.g. C. Bratu, 'Authorship', in Dunphy (ed.), Encyclopedia, pp. 133-136.

11 G. Genette, Palimpsestes, la littérature au second degré (Paris, 1982). Genette also mentions the possibility of auto-hypertextuality, rewriting of the author's own work, which is a case we see repeatedly in fifteenth-century historiography in the Low Countries. 
contact with each other, interacted, and exchanged information, such as texts and manuscripts, with each other.

Such human networks are studied extensively for the Early Modern period in which they are acknowledged to have stimulated the circulation of knowledge. ${ }^{12}$ For the Middle Ages, such networks have remained more obscure. A lack of relevant sources is undoubtedly an obstacle. A good example, however, is the group of fourteenth-century Rhineland mystics known as the Gottesfreunde who were known to exchange texts, letters, and manuscripts with counterparts in the Low Countries. ${ }^{13}$ Others include, or may include, the collaborative nature of Hildegard of Bingen's oeuvre, recently examined using non-traditional authorship attribution techniques. ${ }^{14}$ In Bremen, a collective of authors contributed to the so-called Rinesberg/Schene-Chronik, written at the end of the fourteenth and beginning of the fifteenth centuries. ${ }^{\text {Is }}$ From the Duchy of Brabant

12 e.g. 'Mapping the Republic of Letters', < http://republicofletters.stanford.edu/> [accessed 16 August 2014]; 'Circulation of Knowledge and Learned Practices in the i 7 th-century Dutch Republic. A Web-based Humanities' Collaboratory on Correspondences', <http://ckcc.huygens.knaw.nl/> [accessed 16 August 2014]; 'Cultures of Knowledge. Networking the Republic of Letters, I5501750', <http://www.culturesofknowledge.org/> [accessed I6 August 2014].

13 G. Warnar, 'Men of letters. Medieval Dutch literature and learning', in M.J.F.M. Hoenen, N. Germann and L. Cesalli (eds), University, Council, City. Intellectual Culture on the Rhine (I300-I550). Acts of the XIIth International Colloquium of the Société Internationale pour l'Étude de la Philosophie Médiévale (Rencontres de philosophie medieval, I2) (Turnhout, 2007), pp. 221-246, here 24I-242.

${ }_{14}$ M. Kestemont, S. Moens and J. Deploige, 'Collaborative authorship in the twelfth century. A stylometric study of Hildegard of Bingen and Guibert of Gembloux', Literary and Linguistic Computing Advance Access (2013), I-26 $<$ doi:I0.1093/llc/fqto63>; the study of collaborative authorship in historic writing is receiving more attention in recent years: e.g. N. Reynolds, G. Schaalje and J. Hilton, 'Who wrote Bacon? Assessing the respective roles of Francis Bacon and his secretaries in the production of his English Works', Literary and Linguistic Computing, 27 (2012), 409-425.

15 There is still controversy as to which author contributed to what: $\mathrm{H}$. Schwarzwälder, 'Die Chronik von Rinesberch und Schene. Verfasser, Bearbeiter, Überlieferung', Bremisches Jahrbuch, 52 (1972), 21-37, here pp. 31-36. This example and other ones are also provided by Stein: Stein, Politiek en historiografie, p. 57 (n. 103); Compare: R. Sprandel, Chronisten als Zeitzeugen. Forschungen zur spätmittelalterlichen Geschichtsschreibung in Deutschland (Kollektive Einstellungen und sozialer Wandel im Mittelalter, N.F. 3) (Cologne/Weimar/ Vienna, 1994), p. 16. 
comes another example of the Tractatulus de laude terrae Brabantiae to which multiple persons contributed. ${ }^{16}$

For the County of Holland, no such chronicles with multiple authors have yet been identified. This may be surprising as the county could fall back on a rich tradition of history writing. Existing chronicles were often copied and combined for decades after their creation, constructing a fine web of interrelated texts on the history of the region. For now, the closest to a possible collaborative effort comes from the anonymous 'Clerc uten Laghen Landen' (Clerk of the Low Countries), perhaps to be identified with Dirc Potter (d. I 428). He worked at the court of Count William VI of Holland. So did the Heraut Beyeren (d. I4I4), the author of one of the main sources for the clerk's chronicle. ${ }^{17}$ In all likelihood, both authors knew each other personally and may have discussed their historiographical interests. However, by the time the Clerc uten Laghen Landen finished his chronicle, presumably in the spring of $\mathrm{I}_{4} \mathrm{I} 7$, Heraut Beyeren had already died and can therefore not have been involved..$^{18}$

In this article, we will show that at the end of the fifteenth century there existed a generation of historiographers in the Low Countries that stood in direct contact with each other and repeatedly exchanged their texts. How far this circle extended is up for debate, but we will show that there are reasons to believe that it might have been much larger than assumed.

We will focus on a selection of a large corpus of chronicles written by a core group of historiographers in the Northern Low Countries. The period these historiographers worked in has recently been characterized by Levelt as a time of 'a revival of Latin history writing by learned clerics in and about Holland.' ${ }^{19}$ The group in question, consisting of three authors, has been studied extensively before, but their exact mutual relationships are still shrouded in clouds. Moreover,

${ }_{16}$ V. Vermassen, 'De Nova historia ducum Brabantiae en het Tractatulus de laude terrae Brabantiae van de Korsendonkse kanunnik Johannes Meerhout', Revue Belge de Philologie et d'Histoire, 88 (2010), 205-220.

17 J.M.C. Verbij-Schillings, Beeldvorming in Holland. Heraut Beyeren en de historiografie omstreeks I40o (Nederlandse literatuur en cultuur in de middeleeuwen, XIII) (Amsterdam, 1995), pp. 262-267; E. Timpener, '“Alsoe die historie seit”. De Clerc uten laghen Landen vanuit een nieuw perspectief,' Jaarboek voor Middeleeuwse Geschiedenis, 13 (2010), 167-209.

18 Verbij-Schillings, Beeldvorming, 35; Timpener, 'Alsoe die historie seit', I83.

19 S. Levelt, Jan van Naaldwijk's Chronicle of Holland. Continuity and Transformation in the Historical Tradition of Holland during the early Sixteenth Century (Hilversum, 2011), p. 58. 
it has been a deliberate choice not to confine ourselves to these three authors. Working from this core group we will extend our view to other historiographers who stood in contact with them, revealing the contours of a larger network of history writers.

By reconstructing such a network, it becomes possible to define and study these authors as a community. We are able to study common goals and incentives, common views on history, their political agendas, if any. We are able to study their specific discourse and what set them apart from other (groups of) individuals in the Low Countries. This community of historiographers touches on the 'textual community' defined by Stock as well as Bizzell's 'discourse community.. ${ }^{\circ}$ Both concepts discuss how a group of people use the same language to produce texts or read and understand a text in a similar way, to such a degree that it influences the life of the group members towards the outside world. The term 'textual communities' is mostly applied by Stock to religious communities, for which texts and their meanings are essential to their general behaviour in life. Bizzell, on the other hand, speaks about academic language and an academic discourse. However, these concepts are usually applied to much more formalised and larger groups and are said to have influenced people's world view in a way not quite appropriate for this community of historiographers. We are therefore inspired by these concepts to look at the common discourse and ideas between the medieval historiographers, but do not attempt to follow these concepts narrowly.

The reconstruction of this network of authors will also be relevant for those who wish to examine how the three writers, and others around them, exerted their authority over the different versions of their texts. ${ }^{21}$ The genre of historiography by definition depends on past authorities, as writers could generally not have experienced all events themselves. The genre is therefore largely dependable on (primarily written) sources on the past. In essence, it is, or at least becomes, an intertextual medium..$^{22}$ This

20 B. Stock, Listening for the text. On the uses of the past (Baltimore/London, 1990); P. Bizzell, Academic Discourse and Critical Consciousness (Pittsburgh/ London, 1992).

${ }^{21}$ In regard to this topic for instance: Hobbins, Authorship and Publicity Before Print, chapter 6.

22 G. Melville, 'Kompilation, Fiktion und Diskurs. Aspekte der heuristischen Methode der mittelalterlichen Geschichtsschreiber', in C. Meier and J. Rüsen (eds), Heuristischen Methode. Theorie der Geschichte. Beiträge zur Historik 5 (Frankfurt a. M., 1988), pp. 133-153 (spec. 134-135). See also: Fisher, Scribal Authorship, 59-60, 74. 
is not necessarily different in the case laid out here, since the exchange of texts (via manuscripts) is also a major characteristic of the interaction between the discussed authors. The social factor in writing these texts does, however, add a new dimension to the way they approached each other in their writings. Such elements can only be studied if the contours of a network of writers have been exposed.

After an introduction of the main group of chroniclers, we will take a more detailed look at the textual and material evidence their chronicles provide in order to study their interdependency. Subsequently, we will introduce the other authors and chronicles that may have belonged to this network of authors. We will then discuss how the exchange in this community of authors might have worked and how this influences views on late medieval history writing in the Low Countries.

\section{A generation of chroniclers}

The aforementioned core group that was part of a late fifteenthcentury generation of chroniclers in the Northern Low Countries, arguably consisted of Johannes a Leydis (d. 1504?), Theodericus Pauli (d. I493/94), and Willem van Berchen (d. >I48I). All three were highly productive historiographers; all three were clergymen, working in urban communities, and without permanent, high status sponsors. Johannes a Leydis (Jan Gerbrandsz. van Leiden) was a Carmelite friar, who lived in the city of Haarlem. He had been prior and subprior of the Carmelite monastery in Haarlem. Except for a brief period when he acted as prior of the Carmelite monastery in Woudsend, Friesland, he thus spent most of his active career in the County of Holland. Although he is most famous for his two chronicles on Holland, he also wrote chronicles on the monastery of Egmond and on the Brederode family. Theodericus Pauli, also known as Dirk Frankensz. Pauw, was a canon priest in Gorinchem, the town where he lived all his life. In reference to his historiographical production, he described himself as 'archichronographus' (arch-chronicler). ${ }^{23}$ Pauli also wrote two chronicles of Holland, but, next to that, he worked on several regional chronicles, a world chronicle, a history of the crusades and hagiography, amongst others. Their contemporary, Willem van Berchen, operated mainly

${ }_{23}$ 'Honorabilis et discreti viri, archichronographi domini Theoderici Pauli presbyteri et canonici ecclesie sanctorum Martini et Vincencii in Gorinchem Traiectensis dyocesis': Trier, Stadtbibliothek [further : SB] Ms. I288/79, f. 2v. 
outside the County of Holland, in the Duchy of Guelders. He, too, became a canon priest, in the city of Nijmegen, as well as a priest in the parish churches of the nearby villages Niel and Cuijk. ${ }^{24}$ Although he is most known for his chronicle on Guelders, a Chronicle of Holland by Berchen, in two parts, survived in a compilation manuscript that included many of his texts. Willem van Berchen enrolled at the University of Cologne in I433. Johannes a Leydis probably visited the same university thirty years later, in $1463 .{ }^{25}$ No university education could be traced for Theodericus Pauli. ${ }^{26}$

As contemporary authors, Pauli, Leydis, and Berchen show an important number of shared characteristics in their history writing. First of all, their taste for subject matters was remarkably similar. Leydis, Pauli, and Berchen all wrote several regional chronicles, of which their Chronicles of Holland will be the primary focus here. The growing interest in the history of noble families in the fifteenth century can also be recognized in their works. For example, both Pauli and Leydis wrote about the Brederode family. Furthermore, these chroniclers shared a preference in choice of language. Even though writing in the vernacular was common in the fifteenth century, they all chose to write (most of) their histories in Latin. ${ }^{27}$ Another interesting feature is that they had a peculiar tendency to

${ }_{24}$ For biographical details: B. Ebels-Hoving, 'Johannes a Leydis en de eerste humanistische geschiedschrijving van Holland', Bijdragen en Mededelingen betreffende de Geschiedenis der Nederlanden, 100 (1985), pp. 26-51, here pp. 30-3I; E.O. van der Werff, 'Ad defendendum terminos christanitatis. Het Liber bellorum dei van Theodericus Pauli (1489)', in B. Ebels-Hoving, C.G. Santing and C.P.H.M. Tilmans (eds), Genoechlike ende lustige historiën. Laatmiddeleeuwse geschiedschrijving in Nederland (Middeleeuwse studies en bronnen, 4) (Hilversum, 1987), pp. IOI-117 (spec. pp. IO2-103); C.P.H.M. Tilmans, 'De Hollandse kroniek van Willem Berchen', Holland. Regionaalhistorisch Tijdschrift, 16 (1984), pp. IOI-121, here pp. 101-102.

25 Ebels-Hoving, 'Johannes a Leydis', 47-48; C.P.H.M. Tilmans, 'De Bourgondische dreiging en de vijftiende-eeuwse geschiedschrijving in Gelre. De kronieken van Willem van Berchen (c. I4I5-na I48I)', Kroniek Arnhem, 5 (1988), pp. 55-67, here p. 56.

26 Only the matriculation registers of Paris, Louvain, and Cologne, the most common universities for students coming from the Low Countries, were examined: Van der Werff, 'Ad defendendum', pp. 102-103.

27 The only two exceptions written in Middle Dutch are the Brederode Chronicle Leydis wrote on behalf of Yolande van Lalaing, wife of Reinoud II van Brederode, and the Chronicle of the lands of Arkel and city of Gorinchem, which is attributed to Pauli. Regarding the authorship of that last text, with references 
keep revising and rewriting their own work, which will be of much help to plot their relationships as we will see. At least one autograph manuscript of each of the three authors has been preserved. These similarities alone justify the thought that the three contemporaries could have been in contact with one another. ${ }^{28}$ Indeed, in the past, several scholars have compared their works and revealed numerous affiliations - an approach that has been severely hindered by the lack of proper editions for many of the texts. However, incomplete and contradictory conclusions make it difficult to form an accurate picture.

It is therefore necessary to have a new look into this network of writers. Several elements of previous research still hold, but after more than two decades of predominantly dormant interest, some of these conclusions need adjustment. As part of the research process, we have found some adjustments to the dates of the examined chronicles, which will be discussed in due course. Moreover, the manuscripts that contain these chronicles are far from exhausted as research objects. Here, we have decided to select a few cross-sections from the Chronicles of Holland written by Leydis, Pauli, and Berchen and examine the affiliations between the texts. Since the influential fourteenth-century chronicle on Holland and Utrecht by Johannes de Beke served as a major source for all of them, determining the affiliation of the texts is a rather delicate process. ${ }^{29}$ Apart from numerous shorter snippets of text, often a selection of available examples, we primarily concentrate on the lists of crusaders that left for the Third Crusade in 1188 (Beke, c. 58b) and two larger cross-sections. One of them treats the Crusade against the Stedingers $(1233 / 1234)^{30}$ and

to other literature: M.J. Waale, De Arkelse oorlog, I40I-I4I2. Een politieke, krijgskundige en economische analyse (Middeleeuwse studies en bronnen, 17) (Hilversum, 1990), pp. 24-25.

28 Though in contrast: C.P.H.M. Tilmans, Historiography and humanism in Holland in the age of Erasmus. Aurelius and the Divisiekroniek of ISI7 (Leiden, 1992), p. 51 (translation of: Aurelius en de Divisiekroniek van I5I7. Historiografie en humanisme in Holland in de tijd van Erasmus (Nieuwkoop, 1992), p. 83.

29 Beke wrote a chronicle of Holland and Utrecht from Roman times until 1346. Later, his text was translated into Middle Dutch and continued until 1393. H. Bruch (ed.), Chronographia Johannis de Beke (Rijks Geschiedkundige Publicatiën: Grote Serie, I43) (The Hague, 1973); H. Bruch (ed.), Johannes de Beke. Croniken van den Stichte van Utrecht ende van Hollant (Rijks Geschiedkundige Publicatiën: Grote Serie, 180) (The Hague, 1982).

30 The narrative of this crusade also appears in another work of Pauli, the Liber bellorum dei (1489). Unfortunately, we were not able to examine this (unpublished) text. Van der Werff, 'Ad defendendum', p. Io8. 
Countess Machteld of Brabant (d. 1267) who married Count Floris IV of Holland (d. 1234) (Beke, c. 69a-69b). The other concerns the murder of Count Floris V of Holland (d. 1296) (Beke, c. 74f-76), which is also a particularly rich source for those scholars interested in the editing techniques of Pauli, Leydis, and Berchen. ${ }^{31}$

These cross-sections were specifically selected, because they appear in all the Chronicles of Holland based on Beke by Leydis, Pauli, and Berchen. Second, we selected sections that could provide enough material on the authors' individual attempts to make minor or sometimes even major alterations to the text or its order. These alterations will help us to uncover the origins, layers, and connections in the chronicles. As we have mentioned in the introduction, our investigation soon opened up onto other contemporary historiographical works. These are a chronicle of the Teutonic Order associated with the land commander of the Utrecht bailiwick Johan van Drongelen, the Croniken van der Duytscher Oirden, and a short text referred to as the Chronicon Hollandiae. Both of these will be discussed later on in this article. In the future, similar findings may well lead to even more related texts to be included in the discussion.

An all-encompassing examination of the content of the chronicles has not been possible within the scope of this article. Nor have we been able to examine all original manuscripts (Table $\mathrm{I}$ ). Some of the manuscripts that we did study were accessed through reproductions and we had to fall back on a few editions as well. Further study and the production of editions of these texts are desirable. The conclusions in this article will provide enough incentive to undertake such an endeavour.

\section{Chronicles of Holland by Leydis, Pauli and Berchen}

The Chronicles of Holland that came into existence in the fifteenth century did not only have a common background (note the addition 'terras et' in Table 2). Table 2 first of all shows how incredibly indebted they still were to the Latin chronicle by Johannes de Beke; it is no wonder that they are sometimes regarded as mere Beke adaptations. During the lifetime of Leydis, Pauli, Berchen, and other members of their generation, their texts became more and more personal as well as complex. In the past, this process has been described as a fairly linear process. One author copied from another, adapted it to his own purposes, and so the

31 Verkaik's examination of the depiction of the murder cannot satisfy those wanting to learn more about the relationship between the aforementioned chronicles: J.W. Verkaik, De moord op graaf Floris $V$ (Middeleeuwse studies en bronnen, 47) (Hilversum, 1996), pp. 36-52 (spec. 38-4I). 
Table I: References to the primary manuscripts used in this essay.

\begin{tabular}{|c|c|}
\hline Reference & Editions and/or manuscripts used in this paper \\
\hline Beke (Latin) & $\begin{array}{l}\text { H. Bruch (ed.), Chronographia Johannis de Beke (Rijks } \\
\text { Geschiedkundige Publicatiën: Grote Serie, 143) (The } \\
\text { Hague, 1973). }\end{array}$ \\
\hline Leydis I & $\begin{array}{l}\begin{array}{l}\text { London, British Library, Cotton Vitellius } \\
\text { (reproductions) }\end{array} \\
\end{array}$ \\
\hline $\begin{array}{l}\text { Copy of Leydis I by } \\
\text { Frederik van Sevender }\end{array}$ & Leiden, Universiteitsbibliotheek, BPL, 127 D \\
\hline Leydis II & $\begin{array}{l}\text { F. Sweertius ed., 'Ioannis Geerbrandi Leydensis, Carmelitani, } \\
\text { Chronicon Hollandiae comitum et episcoporum } \\
\text { Ultraiectensium..., in Id., Rerum Belgicarum annales chronici et } \\
\text { historici. De bellis, urbibus, situ, \& moribus gentis, antiqui recen- } \\
\text { tioresque scriptores... I (Frankfurt am Main, 1620) pp. 1-349. }\end{array}$ \\
\hline Pauli I & Utrecht, Universiteitsbibliotheek, Hs. 1650 (reproductions) \\
\hline Pauli II & Trier, Stadtbibliothek, Hs. 1288/79 (reproductions) \\
\hline Berchen & $\begin{array}{l}\text { C.P.H.M. Tilmans, De Hollandse kroniek van Willem } \\
\text { van Berchen (unpublished MA thesis, Rijksuniversiteit } \\
\text { Groningen) (Groningen, 1982). }\end{array}$ \\
\hline \multirow[t]{2}{*}{ Chronicon Hollandiae } & Brussels, Koninklijke Bibliotheek, Ms. 5376-5378 \\
\hline & $\begin{array}{l}\text { H. Obreen (ed.), 'Chronicon Hollandiae (-1459)', Bijdragen } \\
\text { en Mededelingen van het Historisch Genootschap, } 46 \text { (1925), } \\
\text { pp. 1-42. }\end{array}$ \\
\hline \multirow{2}{*}{$\begin{array}{l}\text { Croniken van der } \\
\text { Duytscher Oirden }\end{array}$} & Vienna, Deutschordenszentralarchiv, Ms. 392 \\
\hline & New edition in preparation by R.J. Stapel. \\
\hline
\end{tabular}

Table 2: Similarities of the late fifteenth-century Chronicles of Holland. The sentence is absent from the Chronicon Hollandiae.

\begin{tabular}{|l|l|}
\hline Chronicle & Passage \\
\hline Beke, c. 69b & $\begin{array}{l}\text { Eodem anno Florencius comes princeps imperterritus multa } \\
\text { tyrocinia per diversas provincias frequentavit }\end{array}$ \\
\hline Leydis I, f. 94r & $\begin{array}{l}\text { Eodem anno Florencius comes princeps imperterritus multa } \\
\text { tirocinia per diversas terras et provincias frequentavit }\end{array}$ \\
\hline Pauli I, p. 262 & $\begin{array}{l}\text { Eodem anno Florentius comes princeps imperterritus multa } \\
\text { tirocinia per diversas terras et provintias frequentavit }\end{array}$ \\
\hline Pauli II, f. 71v & $\begin{array}{l}\text { Eodem anno Florencius comes princeps imperterritus multa } \\
\text { tyrocinia per diversas terras et provincias frequentavit }\end{array}$ \\
\hline Berchen, c. 33 & $\begin{array}{l}\text { Eodem anno Florencius comes princeps imperterritus multa } \\
\text { tyrocinia per diversas terras et provincias frequentavit }\end{array}$ \\
\hline $\begin{array}{l}\text { Leydis II, } \\
\text { p. 194 }\end{array}$ & $\begin{array}{l}\text { Anno Domini 1235. Florentius Hollandiae Comes, Princeps imper- } \\
\text { territus, multa tirocinia per diuersas terras \& prouincias frequentauit }\end{array}$ \\
\hline
\end{tabular}


corpus evolved. As will become clear through this article, the reality is much more complex, with authors almost constantly in contact with one another and exchanging their views on history.

The chronicles have been compared before, but with different conclusions. Bruch and Carasso-Kok stated that Leydis copied information gained from Pauli's Chronicle of Holland..$^{22}$ Bruch even went so far as to assume animosity between the two. Van der Werff convincingly rejected such rivalry and referred to them rather as 'helpful colleagues' who shared texts both ways. ${ }^{33}$ The most recent views are represented by Van der Werff, Ebels-Hoving, and Tilmans. According to Van der Werff, Pauli first wrote an adaptation of the aforementioned fourteenth-century chronicle by Johannes de Beke (hereafter: Pauli I). Pauli then wrote a second Chronicle of Holland (Pauli II), which Van der Werff qualified as an adaptation of a Beke-adaptation Leydis made earlier (Leydis I). ${ }^{34}$ For his own revised Chronicle of Holland (Leydis II), Leydis turned to both texts of Pauli for information as well as to his own earlier text Leydis I. ${ }^{35}$ Willem van Berchen has been identified as a consumer of one or both of Pauli's Chronicles of Holland and Pauli, in turn, used at least one of Berchen's chronicles. ${ }^{36}$

First, let us discuss the texts in a chronological order. Johannes a Leydis wrote his first Chronicle of Holland in $1466 .{ }^{37}$ The text is transmitted through a damaged autograph now kept in London. The final pages are missing and the chronicle ends abruptly in 1437 . However, the extent

32 H. Bruch, Supplement bij de geschiedenis van de Noord-Nederlandsche geschiedschrijving in de Middeleeuwen van J.M. Romein (Haarlem, 1956), pp. 43-46; M. Carasso-Kok, Repertorium van verbalende historische bronnen uit de middeleeuwen. Heiligenlevens, annalen, kronieken en andere in Nederland geschreven verhalende bronnen (The Hague, 198I), p. 327.

33 E.O. van der Werff,'Twee Egmondse abtenlijsten in de werken van Theodericus Pauli (c. 1417-1493)', in G.N.M. Vis and M. Mostert (eds), Heiligenlevens, annalen en kronieken. Geschiedschrijving in middeleeuws Egmond (Egmondse studiën, I) (Hilversum, 1990), pp. I45-168 (spec. 158-159). See also: EbelsHoving, 'Johannes a Leydis', 4I (note 69); This does not mean that their chronicles agree on everything. Van Moolenbroek, for example, who examined the versions of the story of the Siege of Damietta could not find any connection between the versions of the siege by Pauli and Leydis: J.J. van Moolenbroek, 'De ketting van Damietta, een Haarlems zaagschip en Willem I van Holland', Jaarboek voor Middeleeuwse Geschiedenis, 14 (2011), $113-149$, here p. I23.

34 Van der Werff, 'Twee Egmondse abtenlijsten', pp. 154-I55, I6I.

${ }_{35}$ Ebels-Hoving, 'Johannes a Leydis', 40.

36 Tilmans, 'Hollandse Kroniek', in. See also note 74.

37 Ebels-Hoving, 'Johannes a Leydis', 33-34. 
of the original text can be reconstructed through a manuscript copy. On 22 August 1469, Frederik van Sevender, a fellow Carmelite friar in Schoonhoven, had finished copying the eighth book of Leydis I and continued to copy the ninth and concluding tenth books. ${ }^{8}$ Previous scholars have always silently assumed that Sevender produced his copy straight from Leydis' autograph given the time between the two manuscripts. ${ }^{39} \mathrm{We}$ have been able to confirm that this is indeed the case..$^{40}$ This is important, since the manuscript copied by Sevender - as far as we have yet been able to determine - does not contain any of the abundant marginalia present in the London manuscript (compare Fig. I below). They must therefore have been added to the manuscript after this copy was made. We will return to these marginalia shortly.

It is thought that Pauli wrote his first Chronicle of Holland between I469 and I475, probably around $147 \mathrm{I}^{{ }^{41}}$ This chronicle was categorized by Van der Werff as 'essentially a fifteenth-century Beke adaptation'. ${ }^{42}$ Pauli's second chronicle, which Van der Werff referred to as a transcript and adaptation of Leydis $I{ }^{43}$ is usually dated between $\mathrm{I} 477$ and $\mathrm{I} 480 .{ }^{44}$

Leiden, Universiteitsbibliotheek [further: UB], BPL, I27 D, f. $86 \mathrm{v}$.

39 Ebels-Hoving, 'Johannes a Leydis', 34.

40 A large section of script on the folios f. 8Iv-83r (Book 8, c. 14-17) in Sevender's manuscript is clearly atypical of the surrounding pages: note the letter ' $r$ ', 'Wilhelmus' and the sudden use of Arabic numerals. This section corresponds exactly (!) to the text between the first word on f. $124 \mathrm{~V}$ and the last word on f. $126 \mathrm{v}$ in Leydis' autograph. There are no quire boundaries that could explain this. It is as if Sevender asked a fellow Carmelite friar to copy precisely the next five pages of the Leydis autograph after which he himself copied the remainder. If Sevender was using another manuscript copy of the chronicle, one would not expect to find the section corresponding with the precise page endings of Leydis' autograph. Leiden, UB, BPL, I27 D, f. 81v-83r; London, British Library [further: BL], Cotton Vitellius E vi, f. 124v-126v.

${ }_{41}$ Van der Werff, 'Twee Egmondse abtenlijsten', p. I47; E.O. van der Werff, De werken van Dirk Frankensz. Pauw (unpublished MA thesis Rijksuniversiteit Groningen) (Groningen, 1983), pp. 53-54, via <http://www.narrative-sources. be> nr. NLo278.

${ }_{42}$ Van der Werff, 'Twee Egmondse abtenlijsten', p. I50.

${ }_{43}$ Ibid., pp. 146, 154-155.

${ }_{44}$ Ibid., pp. I47-I48; We have chosen to adhere to these dates, but it would be preferable to have the dates of Pauli I and Pauli II reassessed in the near future. Take, for instance, Pauli II. As a digression, Pauli included a history of the noble family of Brederode in Pauli II (see below), in which he stated that he wrote this piece in his 6rst year: Trier, SB, Ms. I288/79, f. 92v; Since Pauli was 
The Chronicle of Holland written by Willem van Berchen (hereafter: Berchen) is part of an interesting autograph manuscript in Brussels. The manuscript contains numerous chronicles - some written by Berchen himself, others he annotated. ${ }^{45}$ This particular chronicle has been dated by Tilmans between I47I and $1480 .{ }^{46}$ She used Pauli I - here dated at I $47 \mathrm{I}$ and identified as one of its sources - as a terminus post quem. The fact that the first part, up to events dated in the year 1428 , reappeared in another chronicle by Berchen, which is dated I475, and the fact that the birth of Margaret of Austria ( 1480 ) is absent, both function as termini ante quos. ${ }^{47}$ Berchen continuously worked on the manuscript. The chronicle consists of two parts, both with a title of their own, which may suggest an independent genesis..$^{8}$ Numerous marginalia can be found in the manuscript, some of which were additions he found in a few of the other chronicles discussed here. ${ }^{49}$ Berchen later inserted two leaves in his text,

born in 1416 or 1417 , the date ranges between 1477 and 1478 . It is, however, unclear whether this date can be projected on the surrounding text as well. Elsewhere in Pauli II, the year 1480 is mentioned, which means that this part must have been written later: ibid., f. $134 \mathrm{~V}$.

45 A sixteenth-century chronicle of the St. Bertin abbey in Saint-Omer was accidently bound together with the autographs. Tilmans, 'Hollandse Kroniek', I03.

46 In another publication, Tilmans dated the chronicle by Berchen between I473 and 1478 , without providing much additional information, apart from the fact that the last event described in the chronicle is dated June I478: Tilmans, 'Bourgondische dreiging', 55, 64.

${ }_{47}$ Tilmans, 'Hollandse Kroniek', 108 (n. 46).

48 Ibid., I09; On some occasions the two parts are referred to as two separate chronicles, but since they were not disseminated on their own, this is uncertain: G.A. Noordzij, 'Willem of Berchen', in Dunphy (ed.), Encyclopedia, pp. 1507-1509.

49 Note, for instance, the marginalia marked by Tilmans with the letter 'c': C.P.H.M. Tilmans, De Hollandse kroniek van Willem van Berchen (unpublished MA thesis Rijksuniversiteit Groningen, 1982), c. 46; This addition can only be found in Pauli I, not in any of the other related and revised chronicles, including Pauli II: Utrecht, Universiteitsbibliotheek [further: UB], Ms. 1650, p. 396; Pauli II: Trier, SB, Ms. I288/79, f. 103r-103v; Leydis I: London, BL, Cotton Vitellius E vi, f. In v; Leydis II: F. Sweertius (ed.), 'Ioannis Geerbrandi Leydensis, Carmelitani, Chronicon Hollandiae comitum et episcoporum Ultraiectensium..., in Rerum Belgicarum annales chronici et historici. De bellis, urbibus, situ, \& moribus gentis, antiqui recentioresque scriptores... I (Frankfurt am Main, 1620), pp. I-349, here 227; Chronicon Tielense: J.D. van Leeuwen (ed.), Auctoris incerti Chronicon 
one of which (c. $34 ; f .323$ ) is of interest to us because it corresponds to a long piece of text found both in Pauli I and Pauli II and is probably taken from the latter. ${ }^{\circ}$

Finally, there is the revised Chronicle of Holland by Johannes a Leydis, Leydis II, which is notoriously hard to date. According to Leydis himself, it took him over ten years to complete the chronicle. Ebels-Hoving tentatively dates the text between $1475 / 80$ to $1485 / 90 .{ }^{\text {si }}$ However, we tend to follow Porck, who proposes a range between 1480 (the latest year mentioned in the text) and 1494 (the last year Maximilian - who is described as 'comes Hollandiae' - acted as regent of Holland)..$^{22}$

\section{Interdependence of the texts - a new proposal}

What then was the exact relationship of the Chronicles of Holland by Leydis, Pauli, and Berchen? Here we will show how much the three authors cooperated and worked in close proximity to each other. Key to understanding the interdependence of these chronicles is the highly intriguing marginalia in the autograph of Leydis $I$.

The marginalia have been the object of scholarly debate. Ebels-Hoving noted that the marginalia were written by several hands, but mostly by Leydis himself. 53 Van der Werff, however, recognized the hand of Pauli

Tielense, sive majoris chronici pars ultima et maxime notabilis... (Utrecht, 1789), p. 268; Latin Beke: Bruch (ed.), Chronographia, c. 75 d.

so The chapter in Berchen does not start with the section 'Anno Domini [...] regis ungarie etc.', as is the case in Pauli I. In Pauli II, this particular section has been removed from this position and repositioned much earlier in the text. Therefore, the structure of Pauli II resembles the inserted leaf more closely. Utrecht, UB, Ms. 1650, p. 267; Trier, SB, Ms. 1288/79, f. 72v; The section was repositioned at: Ibid., f. $7 \mathrm{Ir}$; The story itself first surfaces in the chronicle by the 'Clerc uten Laghen Landen': B.J.L. de Geer van Jutphaas (ed.), Kronijk van Holland van een ongenoemden geestelijke (gemeenlijk geheeten Kronijk van den Clerc uten Laghen Landen bi der zee) (Werken uitgegeven door het Historisch Genootschap gevestigd te Utrecht, Nieuwe Reeks, 6) (Utrecht, I867), pp. 87-88; For the other inserted leaf that contains a text found in the chronicles of Beke, Leydis, and Pauli: Tilmans, De Hollandse kroniek (thesis/ edition), c. 45, f. 327.

51 Ebels-Hoving, 'Johannes a Leydis', 35 .

52 M.H. Porck, De Brederodekroniek van Jan van Leiden (unpublished M.Phil. thesis) (Leiden, 2010), p. 2 I.

53 Ebels-Hoving, 'Johannes a Leydis', 34 (n. 40). 


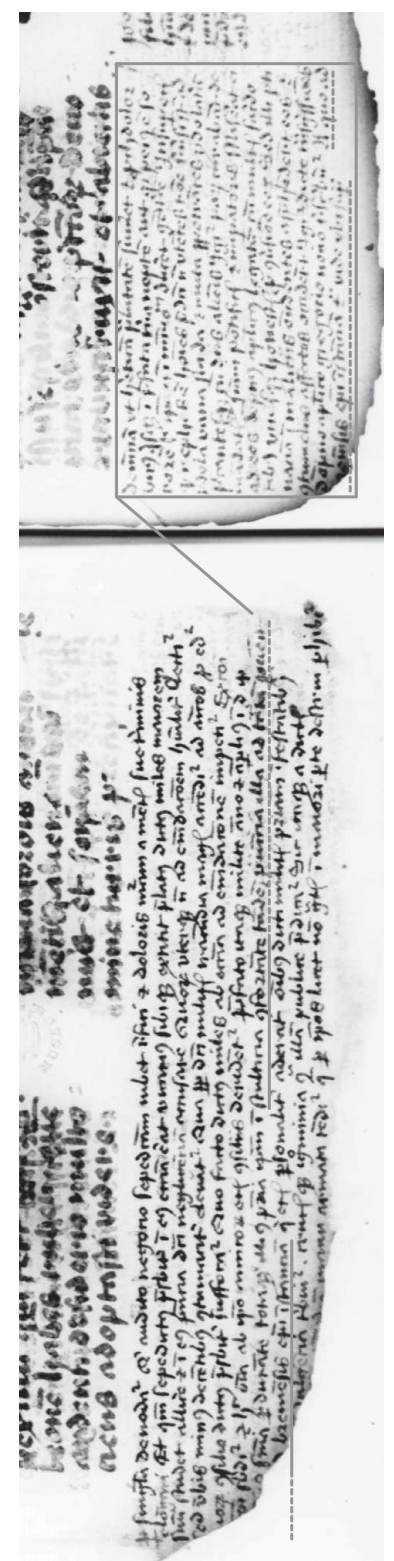

Fig. I: Marginalia in Leydis I: direct use of sources (Procurator). The steps in the procedure are as follows: 1 ) Leydis wrote the body of the text in two columns. 2) The first marginalia were added using Procurator as a source. 3) A new piece of text was added using pointers to show where it should be inserted in the Procurator section. 4) A sentence by Procurator was altered to create a smooth transition between the pieces of text. 5) Other Chronicles of Holland copied the marginalia, including the new addition, obscuring all signs that the text once existed of two separate entities. 
in the marginalia at 'various locations' as well. ${ }^{54} \mathrm{~A}$ quick examination of the London manuscript confirms immediately that not all marginalia are written in the same hand, nor were they all written at the same time." At least two hands can be distinguished in the more substantial sets of marginalia and possibly several (presumably much later) hands are responsible for further minor additions. Many of the marginalia are written in an untidy script, which makes it difficult to compare to Leydis' regular hand of the main text. Nevertheless, some of the writings in the margins leave little room for doubt that Leydis himself wrote them, although it is difficult to determine whether he was the prime contributor to the marginalia. Pauli indeed contributed to the manuscript as well. A folio that was originally left blank was filled with shorter pieces of text written in his hand, including two poems. ${ }^{.6}$ However, it appears that he was not responsible for much of the marginalia elsewhere.

Ebels-Hoving was rather reluctant to identify the sources for these marginalia. Instead of recognizing Theodericus Pauli as one of the providers of information as others did before her, ${ }^{57}$ she simply acknowledged that some of the marginalia could also be found in the Chronicles of Holland by Pauli, without suggesting who borrowed from whom. ${ }^{8}$ Van der Werff went further and suggested that Pauli II was based on the autograph and marginalia of Leydis I (see earlier, note 34). However, in contrast to Van der Werff's suggestion, we have found that Pauli I is related to the autograph rather than Pauli II. Although Pauli's second Chronicle of Holland also includes all marginalia of Leydis I, these are likely accessed indirectly through the use of Pauli $I .99$

54 Van der Werff, 'Twee Egmondse abtenlijsten', p. I6I.

55 Take, for instance, these two opposite pages, with marginalia that seem to have been written by two (or even three) hands: London, BL, Cotton Vitellius E vi, f. $152 \mathrm{~V}-\mathrm{I} 53 \mathrm{r}$.

56 Ibid., f. $2 \mathrm{r}-2 \mathrm{v}$; The poems are also present in the autograph that contains

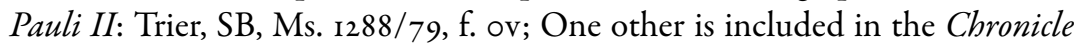
of Holland by Willem Hermans (c. I5I4): Alkmaar, Regionaal Archief, I28 A I, f. IV.

57 e.g.: Bruch, Supplement, 45.

58 Ebels-Hoving, 'Johannes a Leydis', 40. Other sources include the Chronicle of Gouda and the chronicle by William Procurator. We were not able to examine the exhaustive list of sources for the marginalia within the scope of this article.

59 The only tangible indication that we found suggesting that Pauli II used Leydis I directly was the order in which a list of dukes and counts that joined the Third Crusade was presented. Here, Pauli II diverges from Pauli I and follows 
With so many works drawing from the same bits of information, it becomes very difficult to distinguish the correct source for a particular passage. However, detailed textual comparisons can help us to exclude the following scenario: the chronicles of Pauli were not the source for the marginalia in Leydis $I$. This is most evident from the following example. In the lower margins of f. $94 \mathrm{r}^{-}-94 \mathrm{~V}$ in Leydis I, a large section is added by an untidy hand which seems to be responsible for most of the marginalia in the manuscript. The text concerns the aforementioned Crusade against the Stedingers and turns out to be a fairly literal transcription of a text composed by William Procurator in the early fourteenth century. ${ }^{60}$ All aforementioned chronicles, except Berchen, include this section almost ad verbatim, including - and this is important - an interpolation that is written on the opposite page (f. $95 \mathrm{r}$ ) and is not part of Procurator (Fig. I) ${ }^{61}$ The writer of the marginalia used (barely visible) pointers to make clear where he wanted to insert this text. He also scraped away (again, barely visible on the photographs) a few words of the original text to overwrite the space with the opening words of his newly added piece of text. ${ }^{62}$ Evidence of the modifications has become completely obscured in all subsequent chronicles where the added section became part of the main

Leydis I, but perhaps this is a coincidence. London, BL, Cotton Vitellius $\mathrm{E}$ vi, f. 8ov; Utrecht, UB, Ms. 1650, pp. 20I-202; Trier, SB, Ms. I288/79, f. 6or.

M. Gumbert-Hepp (ed.), Willem Procurator. Kroniek (Middeleeuwse studies en bronnen, 76) (Hilversum, 200I), pp. I20, I22.

${ }_{61}$ Utrecht, UB, Ms. I650, p. 26r; Trier, SB, Ms. I288/79, f. 7Ir-7Iv; H. Obreen (ed.), 'Chronicon Hollandiae (-1459)', Bijdragen en Mededelingen van het Historisch Genootschap, 46 (1925), I-42, here pp. 19-20; Sweertius (ed.), 'Chronicon Hollandiae comitum', 193; In contrast: Tilmans, De Hollandse kroniek (thesis/ edition), 32 (edition).

62 Procurator gives the following text: '...stultitia confortante dicta transgressio apostolico scribitur. A quo ad Bremensis episcopi instantiam..., which fits perfectly in the text of the original marginalia: Gumbert-Hepp (ed.),Willem Procurator, 122; This is changed into: '...[stulticia confortante], tandem provincia illa ad tantam pervenit dementiam, vt hereticam pravitatem sumeret, et prochdolor vnusquisque in prefata terra neptem, aut quod peius est sororem, vel ipsam in matrimonium duceret genitricem. Insuper etiam quod nephas est homines predicti, non vtentes ratione, reversi sunt ad ydola vana, surda et muta, perpetrantes ydolotriam, peccantes cum diis alienis. Igitur parum curabant de mandatis summi pontificis et imperatoris. Miserat enim ad eos dominus apostolicus legatum cum multis sacerdotibus, virisque honestis pro conversione eorum. Sed illi, pertinaciam in maliciis ostendentes, apprehenderunt eos, et contumeliis affectos occiderunt. Igitur dicte transgessiones dompno apostolico gregorio nono rescribuntur. 
Table 3: Complex reciprocal relationship between the Chronicles of Holland.

\begin{tabular}{|l|l|}
\hline Chronicle & Passage \\
\hline Beke, c. 63e & $\begin{array}{l}\text { Interea Wilhelmus Comes cum expedicione valida de Zelandia } \\
\text { potenter adveniens, tabernacula sua fixit in Tol, ut alterna die } \\
\text { contra Ludovicum comitem indilate confligeret et eundem ab } \\
\text { hereditate paterna procul expelleret. }\end{array}$ \\
\hline $\begin{array}{l}\text { Leydis I, f. 87v } \\
\text { Fredentical to ms. } \\
\text { Sevender, f. 57v) }\end{array}$ & $\begin{array}{l}\text { Interea Wilhelmus Comes cum expedicione valida, cooperiens } \\
\text { superficiem sicut locuste a Zeelandia potentissime ad veniens } \\
\text { tabernacula sua fixit in Tol* ut alterna die contra Ludowicum } \\
\text { Comitem indilate, confligeret et eundem ab hereditate paterna } \\
\text { procul expelleret. }\end{array}$ \\
\hline $\begin{array}{l}\text { Marginalia } \text { Leydis } \\
\text { I, f. 87v }\end{array}$ & $\begin{array}{l}\text { *) } \text { et deinde circa noctem castrametatus est apud } \\
\text { Scakenbosch }\end{array}$ \\
\hline Pauli I, p. 229 & $\begin{array}{l}\text { Interea Wilhelmus Comes cum expeditione valida de Zelandia } \\
\text { potenter adveniens tabernacula sua fixit in Tol, deinde in } \\
\text { Rijswijck prope Haghis, deinde circa noctem castrametatus } \\
\text { fixit } \text { apud Schakenbusch ut alterna die contra Ludovicum } \\
\text { Comitem indilate confligeret et eundem ab hereditate paterna } \\
\text { procul expelleret. }\end{array}$ \\
\hline Berchen & $\begin{array}{l}\text { Interea Wilhelmus Comes cum expedicione valida de Zelandia } \\
\text { potenter adveniens tabernacula sua fixit in Tol deinde in } \\
\text { Rijswijck prope Haghis. Deinde circa noctem castrameta- } \\
\text { tus fixit apud Scakenbosch ut alterna die contra Ludovicum } \\
\text { Comitem indilate confligeret et eundem ab hereditate paterna } \\
\text { procul expelleret. }\end{array}$ \\
\hline p. 178-179 & $\begin{array}{l}\text { Interea Wilhelmus Comes, cum expeditione valida cooperiens } \\
\text { superficiem terrae à Zelandia veniens, potentissime taber- } \\
\text { nacula sua fixit in Thol, } \text { et deinde circa noctem castrameta- } \\
\text { tus est apud Schakern brusch, vt altera die contra Luduicum } \\
\text { Comitem indilate confligeret, \& eundem ab haereditate } \\
\text { paterna procul pelleret. }\end{array}$ \\
\hline
\end{tabular}

body of the text. Therefore, we must conclude that the original marginalia in Leydis I, rather than an independent adaptation of Procurator or other chronicles, was the source used by all other chronicles.

With that in mind, we can take a closer look at the texts to see how they relate to each other. Table 3 shows a comparison of an exemplary section,

A quo ad bremensis episcopi instanciam, et vide vbi supra': London, BL, Cotton Vitellius E vi, f. 94v-95r. A source for this passage could not yet be identified. 
drawn from several Chronicles of Holland, concerning the war of succession between Count William I of Holland and Count Louis II of Loon (1203-1206). As one would expect from the discussion above, the addition in the margin of Leydis I regarding the encampment at Schakenbosch (between Leiden and The Hague) is included in Pauli I, Pauli II, as well as in Leydis II. For his revised Chronicle of Holland, Leydis used his interpolated autograph, as can be deducted from the small adjustment in Leydis I to the Beke text ('covering the surface like locusts', slightly modified in Leydis II) and other minor variations in the text. The text of Pauli II is identical to Pauli I, including the addition 'afterwards in Rijswijk near The Hague' that is absent from the chronicles of Leydis. Judging from this section, which serves as an example, we can conclude that both Pauli and Leydis used their own chronicles when they wrote their revisions. What also stands out is that the original reading in Beke, without the reference to the covered surface, is preserved in the chronicles by Pauli. Even though Pauli used Leydis I for its marginalia, it could not have been his only source. Rather, Pauli must have worked from another Beke adaptation, similar to Leydis $I$, which he interpolated using the marginalia of Leydis $I^{{ }^{63}}$

The only two of our Chronicles of Holland not to include the marginalia are the manuscript copy of Leydis $I$ by Frederik van Sevender and, strangely enough, Berchen. Tilmans identified the so-called Chronicle of Gouda, Berchen's first Chronicle of Guelders, the Chronicon Tielense, Pauli's Historia de cladibus Leodiensium, and, last but not least, Pauli I as sources of the Chronicle of Holland by Willem van Berchen. ${ }^{64}$ There is indeed ample evidence that Willem van Berchen used one of Pauli's Chronicles of Holland as a source for his chronicle rather than Beke directly or any of Leydis' chronicles (for instance: Table 4). Textual comparisons show it is indeed Pauli's first version - or rather a similar manuscript as we will demonstrate - that Berchen used, although we have previously seen he may have consulted Pauli II while revising his text. ${ }^{65}$ However, so far we were not able to find evidence that any of the marginalia of Leydis $I$, which are included in the main body of the text

63 There is ample other evidence of the close affiliation of Pauli I to Beke (rather than Leydis I) to be found in the chronicles. See, for instance, the comments in note iIs and the word 'recenter' in Table 4 below.

${ }_{64}$ Tilmans, 'Hollandse Kroniek', I09-III, II8.

65 Examples can be found in note 49 and 50 . Also compare 'Fuit idem [...] Gerardi stuperaret': Tilmans, De Hollandse kroniek (thesis/edition), c. 47; against 'Fuit itaque [...] Gherardi stupraret': Utrecht, UB, Ms. 1650, pp. 392-393; Pauli II completely rearranges the order, but there is no sign of this section anymore: Trier, SB, Ms. I288/79, f. IO2r-103r. 
Table 4: The Chronicle of Holland by Willem van Berchen in comparison with the chronicles of Pauli and Leydis.

\begin{tabular}{|l|l|}
\hline Chronicle & Passage \\
\hline Beke, c. 69b & in vindictam agnati sui recenter occidit \\
\hline Leydis I, f. 94v & in vindictam cognati sui crudeliter occidit \\
\hline Pauli I, p. 265 & in vindictam agnati sui recenter ocissi occidit \\
\hline Pauli II, f. 72r & in vindictam agnati sui recenter ocissi occidit \\
\hline Berchen, c. 33 & in vindictam sui agnati recenter ocissi occidit \\
\hline Leydis II, p. 194 & in vindictam cognati sui crudeliter occidit \\
\hline
\end{tabular}

of Pauli I, found their way into Berchen. Take the following example regarding the siege of Kaiserswerth (1247/48). In the margins of Leydis I a few words are added, again taken from the chronicle of William Procurator, regarding the betrothal of the niece of King William II of Holland, daughter of Dirk van Brederode, to the lord of the castle. ${ }^{66}$ These lines were included at the intended location in Pauli I, where they were incorporated in the regular text and cannot be recognized as additions. ${ }^{67}$ Berchen does include all the surrounding text present in both Leydis $I$ and Pauli I, but there is no sign of the marginalia. ${ }^{68}$ Instead, Berchen includes a few sentences on Count Otto of Guelders, similar to a section of Berchen's first Chronicle of Guelders. ${ }^{69}$ For just these particular sentences, one can assume he deliberately replaced it; however, all other marginalia on this folio and the next are also missing in Berchen, while present in Pauli I. $^{\circ}$

This presents us with a dilemma. Berchen is clearly related to the Chronicles of Holland by Pauli, but Pauli I, which incorporates the

$\overline{66}$ London, BL, Cotton Vitellius E vi, f. ıoor; Gumbert-Hepp (ed.), Willem Procurator, pp. 126-I27.

67 Utrecht, UB, Ms. 1650, pp. 308-309; Compare Pauli II: Trier, SB, Ms. 1288/79, f. 8 or.

${ }_{68}$ Tilmans, Hollandse kroniek (thesis/edition), c. 36-37.

${ }_{69}$ L.A.J.W. Sloet van de Beele (ed.), Wilhelmus de Berchen, rector parochialis ecclesie Nyell, Duyflie. De nobili principatu Gelrie et eius origine (The Hague, 1870), pp. 64-65.

70 These marginalia include information that can easily be considered interesting to a historiographer outside the County of Holland. Only one addition in the margin (in a different hand; f. 99v) was not included elsewhere. London, BL, Cotton Vitellius E vi, f. 99v-rorr; Tilmans, De Hollandse kroniek (thesis/ edition), c. 36-37; Utrecht, UB, Ms. 1650, pp. 307-315. 
marginalia in Leydis $I$, was not its source. The conclusion must be that both Berchen and Pauli I shared a common source. In essence, this would have been another Beke adaptation, just like Leydis $I^{71}$ Theoretically, Pauli himself could have made this Beke adaptation. This would render Pauli I as a first revision and Pauli II a second revision of his Chronicle of Holland. However, the text could also have been written by someone else. The only thing that is certain is that this proposed manuscript formed the basis for both Pauli I and Berchen. Perhaps a closer examination of these two chronicles in comparison to the other texts can in the future reveal some characteristics of their shared exemplar.

By examining the marginalia in the autograph manuscript of Leydis I, and their presence and absence in the other Chronicles of Holland, we have been able to construct a fairly clear picture of the complex relations between the texts. Their interdependence forms the heart of the schema presented later on in this paper (Fig. 5). The aforementioned chronicles are, however, also connected in other ways. Note that Leydis used both Pauli $I^{72}$ as well as Pauli $I I^{73}$ for his revised Chronicle of Holland (Leydis II). Nor should this network of texts be confined to Leydis', Pauli's, and Berchen's Chronicles of Holland alone. Pauli II inserted a poem on Duke Henry of Brabant at the Crusade against the Stedingers that also appears in Willem van Berchen's Chronicle of Brabant, written just a few years earlier,

71 Both texts were based on a fairly similar manuscript that belonged to group A of Beke. Note, for instance, 'glorie' instead of 'victorie' (Beke, mss. A; line 19) and 'edificaret' replaced by 'fabricaret' (Beke, ms. A3; line 56): both in accordance with the readings in Pauli, Leydis, and Berchen. Bruch (ed.), Chronographia, c. 69b; e.g: Utrecht, UB, Ms. I650, p. 266; Trier, SB, Ms. I288/79, f. 7Iv; London, BL, Cotton Vitellius E vi, f. 94v; Tilmans, De Hollandse kroniek (thesis/edition), c. 33; See also: Bruch (ed.), Chronographia, x.

72 Compare for instance the section concerning the lord of Heusden: Utrecht, UB, Ms. 1650, pp. 378-379; Sweertius (ed.), 'Chronicon Hollandiae comitum', 224; This is absent from Pauli II: Trier, SB, Ms. I288/79, f. Iorr; Instead, Pauli II inserted a complete chronicle of the Heusden family just before: Ibid., f. 95v-roov; Also compare 'Fuit itaque [...] pulchram nimis': Utrecht, UB, Ms. 1650, pp. 392-393; and 'Porro Gherardus [...] Cronenborch habitationem': Sweertius (ed.), 'Chronicon Hollandiae comitum', 225-226; Absent: Trier, SB, Ms. I288/79, f. IO2r-IO2v.

73 There are numerous similarities, but compare for instance the section 'Sicut prefatus [...] effecti': Trier, SB, Ms. I288/79, f. 7Iv; Sweertius (ed.), 'Chronicon Hollandiae comitum, 193 , lines $30-38$ and especially $33-37$. 
between 1470 and $1475 .{ }^{74}$ Berchen, in turn, consulted Pauli's Chronicles of Holland for his second Chronicle of Guelders. ${ }^{75}$ Any future examinations of other parts of their entire oeuvre will probably reveal more connections.

Below we will give some further examples of contemporary authors that drew from the chronicles by Leydis et al.. Now we will turn to two of these examples that stand out because of their role within the community of writers surrounding Leydis, Pauli, and Berchen. The first is a Middle Dutch chronicle on the Teutonic Order and the person responsible for its content; the second a short chronicle of Holland, best known as the Chronicon Hollandiae.

\section{Drongelen}

One of the contacts of both Leydis and Pauli was Johan van Drongelen, who, until now, has not usually been associated with writing historiography. Drongelen was land commander of the Utrecht bailiwick of the Teutonic Order from I 469 to his death on Is August I492. He entered the order as knight brother in the mid to late I44OS and throughout his career he was wellacquainted with several members of the nobility and high clergy. Before his position as land commander, he was appointed commander of Schelluinen in I45I, a village within walking distance from Pauli's hometown Gorinchem, and, in 1463 , he became commander of Middelburg in Zeeland. ${ }^{76}$

Pauli is the first to record his relationship with Drongelen. According to Pauli, many people had asked him to write the 'true and undisputed' history of the noble Brederode family, since so many biased things, 'out of favour or hatred', were said of the family's origin. In particular, Pauli adds, he was asked by Johan van Drongelen and a certain Jacob Willemsz., who was an otherwise anonymous subprior of the Canons Regular of Mount

${ }_{74}$ 'De quorum victoria hec metra habentur...': Trier, SB, Ms. I288/79, f. 7Iv; C.A. Rethaan Macaré, 'Oude Kronijk van Brabant', in Codex diplomaticus Neerlandicus. Verzameling van oorkonden, betrekkelijk de vaderlandsche geschiedenis. 2 3.I (Utrecht, I855), pp. 3-85 (spec. 63); Tilmans, 'Bourgondische dreiging', 55 .

75 Tilmans, 'Hollandse Kroniek', $\mathbf{2} 2$.

${ }^{76}$ A full biography, as well as his involvement in genealogy and heraldry of noble families, including his own (see below), will be further explored in the forthcoming dissertation by Rombert Stapel. J.J. de Geer van Oudegein, Archieven der Ridderlijke Duitsche Orde, Balie van Utrecht, II (Utrecht 1871), nr. 564 (n. I); Utrecht, Archief van de Ridderlijke Duitsche Orde, balie van Utrecht, inv. nrs. 251, 2525-4. 
Zion near Delft.77 Why Drongelen - or Jacob Willemsz. for that matter was interested in the Brederode family is unclear. But when Drongelen took the habit of the Teutonic Order, the first two names on the list of noblemen invited, 'since they were his kinsmen, etc.', were Reinoud II van Brederode and his brother Gijsbrecht van Brederode. ${ }^{78}$ The list of women began with three names of people who were all members of the Brederode family as well, directly or by marriage.

Johan van Drongelen's own family background is definitely intriguing, but there is little reason to assume that he was closely related to the Brederode family. Throughout his active life, Drongelen showed a clear appetite for genealogy, heraldry, and noble ancestry. One of the expressions of this interest can be found in the development of his own coat of arms (Fig. 2). It appears that he was widely regarded by his contemporaries as an authority on the subject. ${ }^{80}$

77 'Et quia plerique de origine sive originale propagacione illustrium et prepotentum dominorum de Brederoden diversimode sompniando ex parcialitate, favore vel odio, loquuntur, ideo ego, Theodericus Pauli, natus de Ghorinchem ac eiusdem ecclesie collegiate Gorinchemensis vicedecanus, anno etatis mee $\mathrm{LXI}^{\circ}$, ob rogatum multorum et precipue nobilis viri domini Johannis de Dronghelen, supremus commendatoris militum ac dominorum Theutonicorum Traiectensis dyocesis, domini ac venerabilis patris Jacobi, filii Wilhelmi, subprioris conventus regulorum canonicorum in Syon prope Delf etc., veram et indubitatam originem scilicet a quibus propagati aut nati sunt cum ipsorum nobilissima genealogia, non accedendo aliqua parcialitatem, favorem aut aliqua hiis similia, sed ex mera et vera iusticia reddendo sibi et unicuique quod suum, est sicut decet': Trier, SB, Ms. I288/79, f. 92v-93r; The name of Jacob Willemsz. is absent from studies concerning the convent: B.A. Vermaseren, Het klooster 'Sancta Maria in Monte Sion' tussen Delft en Rijswijk 1433-1574. Een vrucht van de Moderne Devotie (Serie-uitgave van het Genootschap Delfia Batavorum, 7) (Pijnacker, 198I); D. van Heel, 'Het Kapittel der Reguliere Kanunniken te Syon bij Delft', Historia. Maandschrift voor geschiedenis en kunstgeschiedenis, Is (1950), I07-II4.

78 'Dit sijn die gene tot Jans cledinge van Drongelen souden wesen als daer hij maech toe is, etc.': Utrecht, Archief van de Ridderlijke Duitsche Orde, balie van Utrecht, inv. nr. 25I. The text is written in Drongelen's own hand.

79 Utrecht, Archief van de Ridderlijke Duitsche Orde, balie van Utrecht, inv. nrs. 249 (1469), 255 (1475), 1353 (1476) and 490 (1481).

80 Compare, for instance, the role of Drongelen in attesting the noble ancestry of Gijsbert van Stoutenburg, professor at the University of Mainz and future canon in Utrecht, in I491: B. van Hoven van Genderen, De heren van de kerk. 

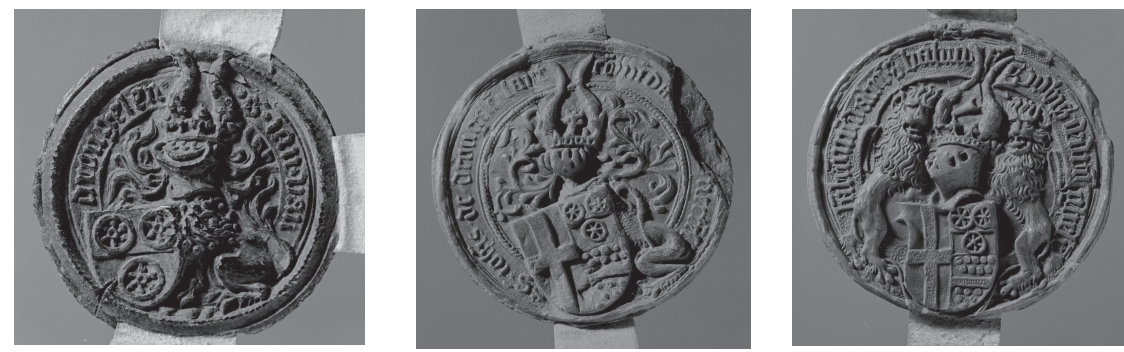

Fig. 2: Development of Johan van Drongelen's seal as Commander of Middelburg (1469) and Land Commander (1476; 1481). A badly damaged applied seal dated I475, divided in four parts with Drongelen in $I$ and 3 and Merwede in 2 and 4 , is not included here. ${ }^{79}$

Johannes a Leydis knew of this reputation as well as he recorded a conversation he had with Johan van Drongelen regarding an investigation into the ancestry of Reinoud II van Brederode. In the Brederode Chronicle written by Leydis between 1475 and I477, Leydis states:

I have heard lord Johan van Drongelen, land commander of the Teutonic House in Utrecht, say that he had held numerous of such letters [concerning the 'true' origin of the Brederode family] in his hand at many locations in Holland, but also that he had some of the same type of letters laying in his convent. ${ }^{8_{1}}$

According to Leydis, the Duke of Burgundy allegedly requested this investigation, using the archives at The Hague and Egmond, when Reinoud was nominated to join the Order of the Golden Fleece in December $1445 .^{82}$ The reputation of Drongelen would have made him an ideal candidate to have carried out the investigation, if there really was

De kanunniken van Oudmunster te Utrecht in de late middeleeuwen (Zutphen, I997), p. 237.

${ }^{81}$ 'Ick heb heer Johan van Dronghelen, den lantcommelduer vanden Duysschen huys binnen Utrecht, horen segghen dat hy dusdanighe brieven in Hollandt tot veel plaetsen in zyn handt ghehadt heeft ende oick mede in zyn clooster zommighe van de selfde forme heeft by hem legghende': Porck, Brederodekroniek van Jan van Leiden, Appendix B (edition), c. II (f. I 5 r).

82 'Doe sende hertoeghe Philips tot Egmont int clooster ende inden Haeghe, om alle die olde scriften te oversien ende doen vantmen altesamen gheloghen': Porck, Brederodekroniek van Jan van Leiden, Appendix B (edition), c. 48; M.J. van Gent, 'Een Hollandse luis in de Bourgondische pels. Het politieke optreden van Reinoud II van Brederode', In het land van Brederode: historisch tijdschrift voor het Land van Vianen, 20 (1995), 2-52, here p. I8. 
one. This may also explain the connection to the Brederode family when Drongelen entered the Teutonic Order around the same time. Perhaps as a consequence of this investigation, Drongelen came into contact with both Leydis and Pauli.

Apart from knowing Pauli and Leydis, Drongelen may well have been a chronicler himself as well. The above passage of Leydis' Brederode Chronicle can also be found in the Middle Dutch Fasciculus temporum, a collection of chronicles printed by Jan Veldener in I480. Here, however, Drongelen's name is absent. Instead it reads:

For I have researched it with all my heart, I was able to find it in old writings and many old sealed letters [...] that I have read, seen, and held in my hands [...] And these letters can be found at many locations in Holland, etc. ${ }^{83}$

Could Johan van Drongelen have been the writer of this part of the Fasciculus temporum? It is a risky question to answer, but it is exciting that the single known reference to a non-printed version of Veldener's Fasciculus temporum spoke of a 'manuscript by the author himself' that also contained a copy of a chronicle of the order to which Johan van Drongelen belonged, the Teutonic Order. It was last seen when brought to auction in $1751 .{ }^{84}$ Other descriptions of the manuscript make clear that

83 'Want ic dat ondersocht hebbe mit ganser herten, so en vijnde ic in ouden scriften ende in veel ouder bezeghelder brieven [...] die ic selve gelesen, ghesien ende in mijn hant ghehat hebbe [...] Ende dier brieven sijn noch veel in Hollant, etc.': J. Veldener (ed.), Dat boeck datmen hiet Fasciculus temporum (Utrecht, I480), f. 285r; Cf. M.H. Porck, 'De Brederodekroniek voor Yolande van Lalaing', in E. den Hartog and H. Wijsman (eds), Yolande van Lalaing (1422-1497), kasteelvrouwe van Brederode (Jaarboek van de Kastelenstichting Holland en Zeeland, 2009) (Haarlem, 2009), pp. 37-67 (spec. 53-56).

${ }_{84}$ The manuscript once belonged to the book collectors Cornelis van Alkemade and Pieter van der Schelling, of which a few folios were published: 'Hier is gevolgd, niet de gedrukte Kronijke van den Jare 1480 , maar het Handschrift van den Schryver selfs; tegenwoordig onder den Uitgever berustende.' C. van Alkemade (ed.), Hollandse jaar-boeken of Rijm-kronijk van Melis Stoke. Behelsende de geschiedenissen des lands, onder de Princen van het eerste huis, tot den jare 1305... (Leiden, 1699), quire sign. : Cccc-Cccc2. The 1751 auction catalogue description is slightly incorrect with regard to the Teutonic Order's history at the end, but comparison to earlier descriptions leave little doubt: 'Manuscripten in Folio, nr. 65. Chronijk van J. Veldenaar over de Keizeren van Romen, Koningen van Engeland, Bisschoppen van Utrecht, Graven van Vlaendre en Holland, Geldre, Kleef en Mark, en beschrijving van de Duitsche Gotten (sic!), met verscheide Genealogische Wapenen, een weinig defect'. 
the part containing a chronicle on the Teutonic Order was in fact a copy of the Croniken van der Duytscher Oirden or Jüngere Hochmeisterchronik. ${ }^{85}$ A primitive synopsis of the opening stages of this chronicle are, in turn, found in the Fasciculus temporum, which is further evidence that both chronicles shared some common background. ${ }^{86}$

The Croniken van der Duytscher Oirden is preserved in numerous manuscripts across Northern Europe. One of these is an autograph or author's copy written in the Utrecht bailiwick in several phases, but primarily around I480 - thus simultaneous to Veldener's Fasciculus temporum - and I491. Some time after I492, perhaps around I496, a few final changes and additions were made. Although the question of authorship is complex, both Johan van Drongelen and a notary public who was probably his secretary, Hendrik Gerardsz. van Vianen, had a substantial role in its creation. In all likelihood, Drongelen was the leading author and collector of sources, the sum of which is close to sixty. ${ }^{87}$

One of those sources for the Croniken van der Duytscher Oirden may have been a short chronicle of the lords of Heusden written by Pauli that

Amsterdam, Bibliotheek van de Vereeniging ter Bevordering van de Belangen des Boekhandels, Nv 208, p. I06. It is absent from subsequent auctions of the same collection in 1848 and 1859: Catalogus van handschriften, oudheden, penningen en munten, in de I7e en de eerste helft der I8e eeuw bijeenverzameld door Korn. van Alkemade en Pt. van der Schelling, verkocht den I7 jan. I848 (Amsterdam, 1848); Catalogus van autographen, bijeenverz. door C. van Alkemade, Pt. van der Schelling en M. van der Houve,..., verkocht 12 apr. I859 (Amsterdam, I859).

85 'Waar in ik, agter de Historie van de Graaven van Cleev, een beschryving vind van de Ridderorde van onze lieve Vrouwe huis te Jerusalem. Als ook van de Hoogmeesteren der Duitsche Order, en een beschryving van de Orde zelve. Mitsgaders een beschryving van de Landcommandeurs van Utrecht, onder dezen titel: Dit syn alle die Lantcommandeurs van der balyen van Utrecht, die gheweest syn, ende hoe langhe dat si elc gheregiert hebben, ende in wat jaer dat si begonde te regieren. Nevens de Wapenen der zelve en hunne couleuren, met de penne geteekend'. A. Pars and P. van der Schelling, Catti aborigines Batavorum. Dat is: de Katten de voorouders der Batavieren, ofte de twee Katwijken, aan See en aan den Rijn... Met aantekeningen; nevens een verzameling van Katwyksche, Rynsburgsche, en andere Nederlandsche oudheden... (New augmented edition: Leiden/Amsterdam/Langerak, 1745), pp. 562-563.

86 Veldener (ed.), Fasciculus temporum, f. $260 \mathrm{r}$.

${ }_{87}$ R.J. Stapel, 'Layer on layer. "Computational archaeology" in 15 th-century Middle Dutch historiography', Literary and Linguistic Computing, 28 (2013), 344-358, here pp. 354-355. More details will be included in the forthcoming dissertation by Rombert Stapel. 


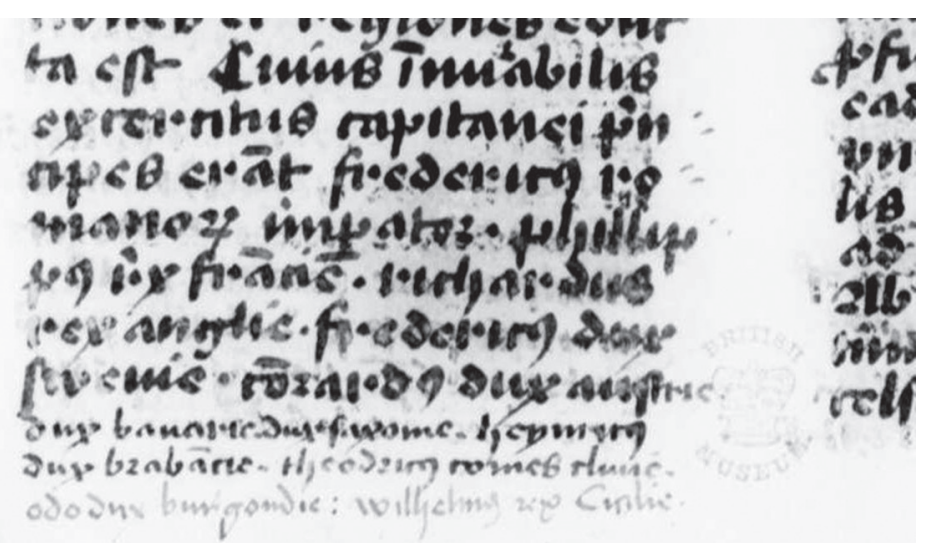

Fig. 3: Marginalia in Leydis I: participants of the Third Crusade (II88).

he included in his Chronicles of Holland, again, possibly linking Pauli and Drongelen together ${ }^{88}$ There is, however, also a connection to the work of Leydis. One particular piece of marginalia in Leydis I added names to the list of the participants of the Third Crusade (Fig. 3). ${ }^{89}$ The last two names of Duke Odo of Burgundy and King William of Sicily seem to have been inserted yet again at a later stage and appear to have been taken from Hartmann Schedel's Weltchronik, also known as the Nuremberg Chronicle, first printed in $1493 .{ }^{\circ} \mathrm{We}$ are inclined to identify the hand of

88 It concerns some specific details concerning the supposed ancestry of two land commanders of the Teutonic Order, Zeger van der Sluis (c. 75I) and Herbaren van Drongelen (c. 756) that resemble the information put forward by Pauli. Pauli I: Utrecht, UB, Ms. 1650, p. 373; Pauli II: Trier, SB, Ms. $1288 / 79$, f. $98 \mathrm{v}-$ 99v. The chapter numbers refer to the new edition of the Croniken van der Duytscher Oirden that is currently in preparation.

89 The added names originally comprised of the Duke of Bavaria, the Duke of Saxony, Duke Henry of Brabant and Count Dietrich of Cleves: London, BL, Cotton Vitellius E vi, f. 8 ov.

90 The slopes of the letters are more upright in comparison to the rest of the marginalia, and the $x$ in 'rex' is very different from all other x's in this example. Furthermore, the names disturb the hierarchy of the list - emperor, kings, dukes, counts - and were not included in any of the subsequent texts that used this list of participants. For their source: Hartmann Schedel, Die Schedelsche Weltchronik. Bibliophilen Taschenbücher 64 (Facsimile print of Nuremberg, I493; Dortmund, 1979), f. 205v. 
the first set of added names as that of Leydis. The names are absent from Pauli I (and Pauli II). ${ }^{91}$

The expanded list of participants of the Third Crusade reappears in three other fifteenth-century chronicles. ${ }^{92}$ These are the Chronicon Hollandiae (see below), Leydis II and the aforementioned Croniken van der Duytscher Oirden..$^{93}$ That last text may have been the source for the names, although the evidence is thin. ${ }^{94}$ However, since that text can be regarded as one of the best informed chronicles concerning the history of the crusades in the Low Countries, it would not be strange for others to consult it as a source for crusade participants. ${ }^{95}$ Furthermore, only in the Teutonic Order does a long tradition exist of dating Duke Henry of

${ }_{91}$ Utrecht, UB, Ms. 1650, pp. 201-202; Trier, SB, Ms. 1288/79, f. 6or; Again, the marginalia did not reach Berchen, but one of the names (Duke Henry of Brabant) does appear - though via a different route. It derived from the Chronicon Tielense, one of Berchen's other major sources. None of the other names are present. Tilmans, De Hollandse kroniek (thesis/edition), c. 20; Van Leeuwen (ed.), Auctoris incerti Chronicon Tielense, 159.

92 The lists of participants in other chronicles do not correspond. For the Chronicle of Gouda: Scriverius (ed.), Goutsche Chronycxken, 46; The Clerc uten Laghen Landen: De Geer van Jutphaas (ed.), Kronijk van Holland, 6o; Veldener (ed.), Fasciculus temporum, f. 288r; See also, following Veldener: A. Janse and I. Biesheuvel (eds), Johan Huyssen van Kattendijke-kroniek: die Historie of die Cronicke van Hollant, van Zeelant ende van Vrieslant ende van den Stichte van Utrecht (Rijks geschiedkundige publicatiën, Kleine serie, IO2) (The Hague, $2005)$, p. 238.

93 Obreen (ed.), 'Chronicon Hollandiae', r6; Sweertius (ed.), 'Chronicon Hollandiae comitum', I69; R.J. Stapel (ed.), Croniken van der Duytscher Oirden (in preparation), c. I13; And in slightly different form: Ibid., c. I17. Since the new edition is currently in preparation, the previous edition (with different chapter numbers) can be found here: Th. Hirsch, 'Die jüngere Hochmeisterchronik', in Th. Hirsch, E. Strehlke and M. Töppen (eds), Scriptores Rerum Prussicarum. Die Geschichtsquellen der preussischen Vorzeit bis zum Untergange der Ordensherrschaft V (Leipzig, I874), pp. I-172 (spec. 52-53) (c. 39, c. 43).

${ }_{94}$ A complete synopsis of all the arguments for and against will be included in the dissertation in preparation by Rombert Stapel.

95 This is largely due to its rich use of sources: e.g. Vincent of Beauvais, the Spiegel Historiael, James of Vitry, William of Tyre, Richard of San Germano, Ludolf of Sudheim, Oliver of Paderborn, and the Middle Dutch Beke. One of the other important chronicles from the Northern Low Countries on the history of the crusades is Pauli's Liber bellorum dei. However, this chronicle was written in I489: almost a decade after this part of the Croniken van der Duytscher Oirden 
Brabant's visit to the Holy Land at I190, instead of $1197 / 1198 .{ }^{96}$ Either way, Leydis learned about these names via the author of the Croniken van der Duytscher Oirden - this particular part of the chronicle was written around I 480 - or he gave Leydis access to his autograph manuscript. Assuming that Johan van Drongelen was the driving force behind the project, it shows that the relationship between Leydis and Drongelen consisted of more than the single reference in Leydis' Brederode Chronicle. Given the fact that Drongelen was also acquainted with Theodericus Pauli and may have used Pauli's writings, Drongelen seems to have established himself within the historiographical circles of the Northern Low Countries.

\section{Chronicon Hollandiae}

The Chronicon Hollandiae is a short, unfinished Latin chronicle written by an anonymous author at the end of the fifteenth century. The oldest manuscript, which is kept in Brussels, shows numerous signs of editing and may be the autograph. ${ }^{97}$ In 1925 , the text was edited by Obreen who claimed the text 'shows a close relationship to the second version of

(c. I480). Unfortunately, we have not been able to examine the manuscript of the Liber bellorum dei. Van der Werff, 'Ad defendendum', p. ıо .

96 Even in the thirteenth-century statutes of the Order, Duke Henry of Brabant is given a prominent place, present at the Order's foundation in I190: M. Perlbach (ed.), Die Statuten des Deutschen Ordens nach den ältesten Handschriften (reprint: Hildesheim/New York, 1975; original: Halle a. S., I890), p. 22; See also the Narratio de primordiis ordinis Theutonici: W. Hubatsch and U. Arnold (eds), 'Anfänge der Deutschordens-Geschichtsschreibung', in Scriptores Rerum Prussicarum. Die Geschichtsquellen der preussischen Vorzeit VI (Frankfurt am Main, 1968), pp. 22-34 (spec. 27). The Chronicon Tielense (and Berchen) also mentions Henry of Brabant, but here, too, a connection to the Teutonic Order could explain the presence of the name. The Chronicon Tielense included numerous rather specific comments on the Teutonic Order, who had one of their largest commanderies in Tiel, and its author likely would have had access to archives of the Order, in Utrecht and/or Tiel, e.g. J. Kuys et al. (eds), De Tielse kroniek. Een geschiedenis van de Lage Landen van de volksverhuizingen tot het midden van de vijftiende eeuw, met een vervolg over de jaren 1552-1566 (Amsterdam, 1983), p. xx, n. 23.

97 Sometimes the manuscript is dated 1515, but this refers to a copy of the Brederode Chronicle by Leydis to which it is bound. A chronicle of the Egmond family completes the present volume. The Chronicon Hollandiae is located at: Brussels, Koninklijke Bibliotheek [further: KB], ms. 5376-5378, f. $37 \mathrm{r}-5 \mathrm{rv}$. 
Johannes a Leydis' Annales. ${ }^{98}$ Following Obreen's observation, Romein suggested the Chronicon Hollandiae could very well be an abstract of this chronicle of Johannes a Leydis or must have been based on a communal source. ${ }^{99}$ In 1956, Bruch suggested that it was based on the first version of Leydis' Chronicle of Holland and called it a 'poor abstract' thereof. ${ }^{100}$ However, others have been critical of this view because of a section at the start of the chronicle. ${ }^{\text {IoI }}$ The London manuscript of Leydis I contains the opening paragraphs of the Chronicon Hollandiae in a slightly different form. ${ }^{102}$ It has been argued that since the text is copied into Leydis' autograph, the Chronicon Hollandiae cannot possibly be an abstract of Leydis I but, rather, must predate it. Recently, this prompted Levelt to argue that 'the work appears to have served as a source to Johannes a Leydis's chronicle of Holland'. ${ }^{103}$

These conclusions were premature. The opening paragraphs of Leydis' Chronicle of Holland in the London manuscript (f. $3 \mathrm{r}-3 \mathrm{v}$ ) are written by a different hand, so far not found elsewhere in the manuscript. The folio may have served originally as a flyleaf and appears to have been left blank at first. On a similar folio, immediately preceding, Pauli wrote several notes. ${ }^{104}$ Therefore, the paragraphs are indeed added later to the existing text of Leydis I and can be considered part of the marginalia. The source for this specific addition is not, however, the Chronicon Hollandiae, but the so-called Chronicle of Gouda or Gouds Kroniekje, from which the text was taken and translated into Latin. ${ }^{105}$ There are

98 H. Obreen (ed.), 'Chronicon Hollandiae', r.

99 J.M. Romein, Geschiedenis van de Noord-Nederlandsche geschiedschrijving in de Middeleeuwen. Bijdrage tot de beschavingsgeschiedenis (Haarlem, 1932), p. III.

100 'Dit povere uittreksel': Bruch, Supplement, p. 4I.

${ }_{101}$ Compare: Carasso-Kok, Repertorium, nr. I79; 'The Narrative Sources from the Medieval Low Countries', NLo554 <http://www.narrative-sources.be> [accessed I6 August 2014].

${ }_{102}$ London, BL, Cotton Vitellius E vi, f. 3r-3v; Obreen (ed.), 'Chronicon Hollandiae', 3-9.

${ }_{103}$ S. Levelt, 'Chronicon Hollandiae', in Dunphy (ed.) Encyclopedia, p. 346.

104 See above, note 56.

105 P. Scriverius (ed.), Het oude Goutsche Chronycxken van Hollandt, Zeelandt, Vrieslandt en Utrecht (Amsterdam, 1663), pp. 2-7. A much longed for new edition is being prepared by Dr. A. Janse (Leiden University). We are grateful for his help in looking for the particular manuscript that could have been used by Leydis, but these efforts have not yet been successful. In marginalia elsewhere in Leydis I (in Leydis' own hand), a story about the city of Heusden is included that could, according to Janse, have derived from a 
Table 5: Comparison of the so-called Chronicle of Gouda, the marginalia of Leydis I and the Chronicon Hollandiae. ${ }^{106}$

\begin{tabular}{|l|l|}
\hline Chronicle & Passage \\
\hline Chronicle of Gouda, p. 3 & $\begin{array}{l}\text { der wilder Neder-Sassen Lant, dat nu ter tijt } \\
\text { Vrieslant hiet }\end{array}$ \\
\hline Marginalia Leydis I, f. $3 \mathbf{r}$ & vagam Saxoniam, modo Frisiam dictam \\
\hline $\begin{array}{l}\text { Chronicon Hollandiae } \\
\text { (Brussels ms.), f. } 37 \mathbf{r}\end{array}$ & vagam Saxoniam, [modo] id est Frisiam \\
\hline
\end{tabular}

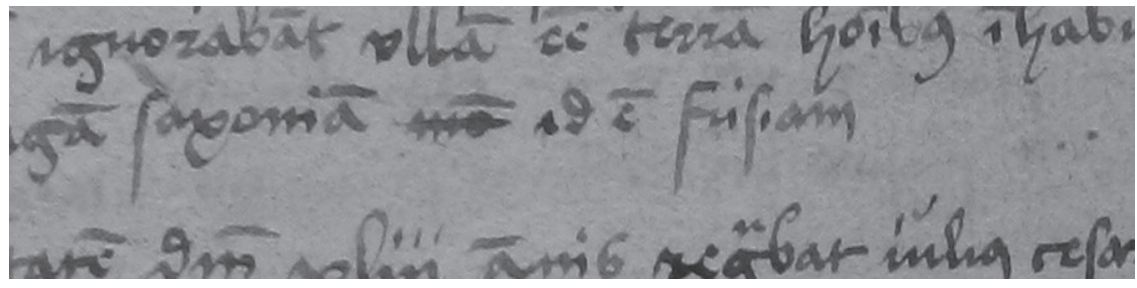

Fig. 4: Alteration in the Chronicon Hollandiae. Brussels, Koninklijke Bibliotheek, ms. $5376-5378$, f. 37 r.

some minor differences between the texts, and it is clear from several textual elements that the Chronicon Hollandiae used this translation as a source for its own introduction to the County of Holland rather than the other way around. Note, for instance, how the word 'modo' (now) was transcribed at first in the Chronicon Hollandiae in accordance to the Leydis I marginalia and the Middle Dutch 'nu ter tijt' of the Chronicle of Gouda, but then crossed out and changed into 'id est Frisiam' (Table 5; Fig. 4).

From the rest of the chronicle it becomes apparent that the Chronicon Hollandiae is almost completely based on the autograph of Leydis I, including its numerous marginalia. ${ }^{107}$ It is also clear that the Chronicon

lost fifteenth-century manuscript of the Chronicle of Gouda from Rotterdam. A seventeenth-century copy is the only extant manuscript that contains the story. London, BL, Cotton Vitellius E vi, f. $139 \mathrm{v}-140$ or; The story is also copied into the Chronicon Hollandiae: Obreen (ed.), 'Chronicon Hollandiae', pp. 24-26.

106 Scriverius (ed.), Goutsche Chronycxken, 3; London, BL, Cotton Vitellius E vi, f. 3r; Brussels, KB, ms. 5376-5378, f. 37 r.

${ }_{107}$ Two especially revealing examples are the sections 'Aurelianensis [...] Burgondie' and 'comes de Wandome [...] Engholesme' when compared with 
Hollandiae did not access the marginalia through a source other than the autograph of Leydis $I$, such as via Pauli I or $I I .^{108}$ When narratives that occur in both Leydis I, Leydis II, and the Chronicon Hollandiae are compared, the Chronicon Hollandiae is repeatedly and evidently closer to Leydis I and even copies parts of it verbatim. ${ }^{109}$ However, the Chronicon Hollandiae is not a mere abstract of Leydis I. It still contains a number of comments and phrases gained from other sources or possibly composed by the author himself. The mentioning of the murder of Emperor Henry VII (d. 1313) is, in this case, especially interesting because it gives a specific source for more information:

In the year 1313 Emperor Henry was poisoned by his confessor, friar Bernard of the Dominican Order, and died, after the poison was put into his cup. See a more elaborate overview of the chronicles about him in St. Catherine's Church in front of the castle of Egmond. ${ }^{110}$

For the story of the Siege of Damietta, the Chronicon Hollandiae also diverges from Leydis $I$ and gives a more Haarlem-centred account of the events. Three times the author changed the text of Leydis I slightly to magnify the role of the citizens of Haarlem, for example, when it is stressed that the fleet that reached Damietta contained 'Haarlemmers in

the marginalia in Leydis I: Obreen (ed.), 'Chronicon Hollandiae', 32; London, BL, Cotton Vitellius E vi, f. Is Ir.

${ }_{108}$ A passage about one of St. Elisabeth's Madonna statues in the church of 's-Gravenzande shows the close connection to the marginalia in Leydis I, instead of Pauli I or Pauli II and Leydis II: Obreen (ed.), 'Chronicon Hollandiae', 20-21; London, BL, Cotton Vitellius E vi, f. 95r; Utrecht, UB, Ms. 1650, pp. 266-267; Trier, SB, Ms. 1288/79, f. 72r; Sweertius (ed.), 'Chronicon Hollandiae comitum', 194-195.

109 Compare, for instance, a passage on Godfrey of Bouillon: Obreen (ed.), 'Chronicon Hollandiae', II-I2; London, BL, Cotton Vitellius E vi, f. 7Ir; Sweertius (ed.), 'Chronicon Hollandiae comitum', I36, I42-144; See for more examples also: J.D.E. de Vries, In search of the medieval 'Anonymous'. On authorship of anonymous medieval chronicles in the Low Countries and the search for the author of the Chronicon Hollandiae (unpublished M.Phil. thesis Leiden University, Leiden, 2012) <http://hdl.handle.net/1887/20353> [accessed 28 November 2013].

110 'Anno Domini 1313 Imperator Henricus a penitenciario suo, fratre Barnardo ordinis Predicatorum, intoxicatur et moritur, veneno immisso in calice. Vide latius compendium cronicarum de eo in ecclesia sancte Catherine ante castrum Egmondense': Obreen (ed.), 'Chronicon Hollandiae', 20. 
particular as well as other most elite knights' instead of only 'most elite weapon-bearers' in Leydis $I{ }^{11}$

The author's access to the library of the castle chapel of Egmond and his interest in the accomplishments of the citizens of Haarlem places him within a clearly defined area in North Holland, close to Johannes a Leydis in Haarlem. ${ }^{\mathrm{II}}$ It is not entirely clear why and for whom the chronicle was written. What we do know is that the author had access to Leydis' autograph with marginalia. Possibly he was an acquaintance of Leydis. On the one hand, the Chronicon Hollandiae can be understood as a working document, organizing information for a chronicle that may or may never have been written. On the other hand, the appearance of the text points in the direction of an independent chronicle. It encompasses a complete chronological range, from the earliest times into the fifteenth century, without notable interruptions. And, although the text closely follows Leydis I and its marginalia, not everything is included in this short chronicle; the writer made specific choices about what to include or to leave out. Explanatory remarks throughout the chronicle and additions, such as the specific interest in the role of the Haarlemmers at Damietta, add to the idea that it has been written with an independent purpose and an audience in mind.

It is difficult to substantiate whether the Chronicon Hollandiae was used as a source itself by the texts discussed here. Textual comparison is challenging since, in general, the text is similar to Leydis I. There are some traces, however, that could indicate that the text was used for Leydis II. Note, for instance, one particular phrase in the Chronicon Hollandiae, absent from Leydis I or its marginalia, pointing out the death of William of Egmond during the Crusade against the Stedingers in $1234 .{ }^{113}$ At this very point in the narrative, perhaps encouraged by that one sentence, Leydis II adds an entire new paragraph 'On the descendants of William

$\overline{111}$ 'Hairlemensibus precipue ac aliis militibus electissimus' versus 'armigeris electissimus. The Chronicon Hollandiae also inserts 'consilio Hairlemensium' and 'adiutorio Hairlemensium' into the narrative. The description of the coat of arms granted to the people of Haarlem as a token of gratitude for their aide differs as well. Obreen (ed.), 'Chronicon Hollandiae', I6-18; Van Moolenbroek, 'De ketting van Damietta', 126.

112 Furthermore, chronicles of the noble families Egmond and Brederode that had their stronghold in the area were bound together with the Chronicon Hollandiae in the Brussels convolute manuscript. From an owner's note in the convolute, we also know that the manuscript was owned by a canon of the Egmond chapter in the sixteenth century: Obreen (ed.), 'Chronicon Hollandiae', 2-3.

113 Ibid., 16. 
Table 6: Comparison of the Chronicles of Holland: the fate of Jacob of Jülich.

\begin{tabular}{|l|l|}
\hline Chronicle & Passage \\
\hline Leydis I, f. 146v & $\begin{array}{l}\text { tandem Deo disponente manifestatur eius malitia quia bulle } \\
\text { ipsius invente sunt false et quod esset episcopus fictus omnibus } \\
\text { manifestatum est }\end{array}$ \\
\hline $\begin{array}{l}\text { Chronicon } \\
\text { Hollandiae, p. 29 }\end{array}$ & $\begin{array}{l}\text { tandem Deo disponente manifestatur eius malitia quia bulle } \\
\text { ipsius invente sunt false omnibusque manifestatum est ipsum } \\
\text { esse episcopum fictum. }\end{array}$ \\
\hline Leydis II, p. 306 & $\begin{array}{l}\text { tandem compertum est, Deo disponente, ipsum esse falsum } \\
\text { episcopum. }\end{array}$ \\
\hline
\end{tabular}

of Egmond.' ${ }^{114}$ Elsewhere, the chronicles describe how Jacob of Jülich was caught imposing as auxiliary bishop of Utrecht and sentenced to death in 1392 (Table 6). The combination in Leydis II'ipsum esse falsum episcopum' more closely resembles the Chronicon Hollandiae than Leydis I." ${ }^{\text {II }}$

The similarities between the Chronicon Hollandiae and Leydis II show that both texts were in some way related to each other. Two scenarios are possible. First, Johannes a Leydis used the Chronicon Hollandiae as a source for his revised Chronicle of Holland as we suggested above. This scenario would provide a terminus ante quem for the Chronicon Hollandiae. On some occasions, however, such as the Siege of Damietta, Leydis II does not incorporate any of the additions made by the author of the Chronicon Hollandiae. ${ }^{116}$

Second, the author of the Chronicon Hollandiae based his chronicle on Leydis I but also included some details from Leydis II. In this case, the date of Leydis II is a terminus post quem. Conclusive evidence of any directionality was extensively sought, but not found. Perhaps an examination of the watermarks in the manuscript that could be the autograph of the Chronicon Hollandiae will point in the direction of one of these scenarios in the future. For now, we can only adhere to the fact that the Chronicon Hollandiae must have been written after the marginalia

114 'De progenie Wilhelmi de Egmonda': Sweertius (ed.), 'Chronicon Hollandiae comitum', 193.

115 The passage originally derived from the Beke-Continuation $V$ : Bruch (ed.), Chronographia, 394 (c. 16); The words 'compertum est' (Leydis II) can be found in Pauli I, who also used the same Beke-Continuation $V$ but stayed much closer to its reading than Leydis I did. Utrecht, UB, Ms. 1650, p. 789. Pauli II stops with the year 1387 and does not contain this event, nor does Berchen.

116 This event is almost identical in both Leydis I and Leydis II, but differs in several ways from the Chronicon Hollandiae. Examples are the roles ascribed to the citizens of Haarlem and the appearance of Haarlem's new coat of arms: Van Moolenbroek, 'De ketting van Damietta', I26, I45-146. 
Table 7: Adjusted dates of the discussed chronicles.

\begin{tabular}{|l|l|}
\hline Chronicle & (Relative) dates \\
\hline Leydis I & 1466 \\
\hline Marginalia Leydis I & Varied; largely: after 1469, before Pauli I (ca. 1471) \\
\hline $\begin{array}{l}\text { 'Beke adaptation' } \\
\text { (Common source } \\
\text { Berchen and Pauli I) }\end{array}$ & Before Pauli I (ca. 1471), before Berchen (<1475) \\
\hline Pauli I & $1469-1475$, ca. 1471 \\
\hline Berchen & Before 1475 (text up to 1428), before 1480 (rest) \\
\hline Pauli II & $1477-1480$ \\
\hline $\begin{array}{l}\text { Croniken van der } \\
\text { Duytscher Oirden }\end{array}$ & Various phases: ca. 1480, ca. 1491, after 1492 (ca. \\
\hline Chronicon Hollandiae & After Marginalia Leydis I, after Pauli I (ca. 1471) ${ }^{117}$ \\
\hline Leydis II & $1480-1494$ \\
\hline
\end{tabular}

of Leydis I. This included the reference to the participants of the Third Crusade mentioned above, but since they were probably not yet present when Pauli I accessed the manuscript (see note 9I), the date of Pauli I can be used as a terminus post quem for the Chronicon Hollandiae. A summary of all the chronicles discussed thus far, as well as their interdependence, can be found in Table 7 and Fig. 5, respectively.

\section{Community of exchange}

With the different Chronicles of Holland now piecing together, the attention can be drawn to the authors again and we can begin to construct an overview. The textual connection between the aforementioned chronicles also implies a certain physical exchange. Agents of this exchange were the manuscripts that contain the texts. A crucial text in the community of historiographers in fifteenth-century Holland was the first Chronicle of Holland by Johannes a Leydis. Evidence indicates that the autograph of Leydis I - the physical object - travelled around the County of Holland. This will serve as an example of how the discussed community of writers functioned.

Leydis' autograph, written in 1466, was first handed over to fellow Carmelite Frederik van Sevender who, in 1469 , and possibly at Schoonhoven, produced a manuscript copy. It was then returned to

117 When Pauli saw the manuscript of Leydis $I$, the additional crusader names were not yet included, but they were present by the time the author of the Chronicon Hollandiae consulted the autograph manuscript. 


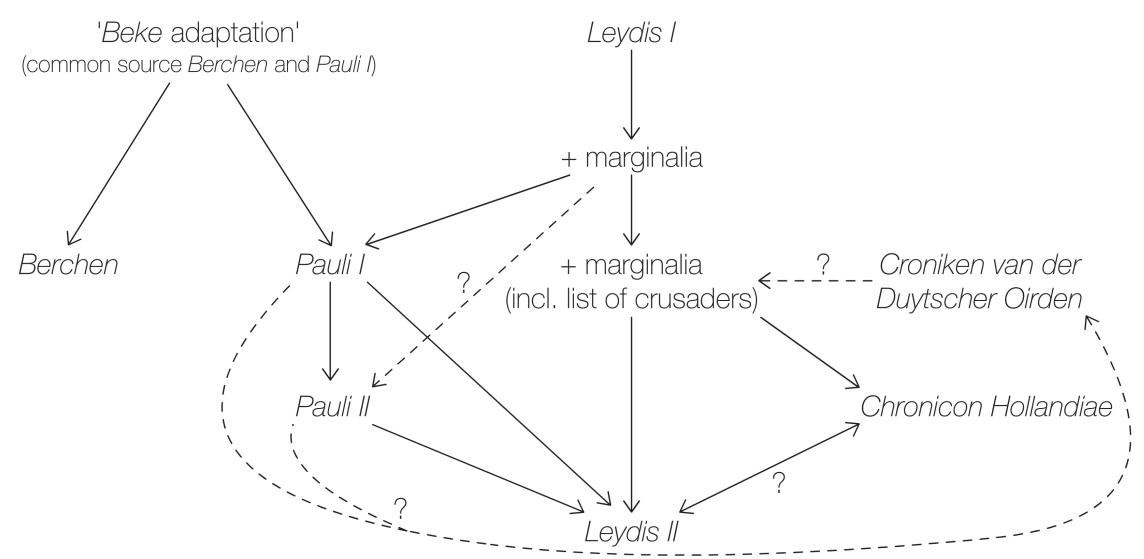

Fig. 5: Schematic view of the interdependency of the Chronicles of Holland mentioned thus far and the Croniken van der Duytscher Oirden.

Johannes a Leydis in Haarlem in order to add numerous marginalia, possibly with the contribution of others. Not long afterwards - Pauli I was composed between 1469 and 1475 (c. I47I) - the manuscript travelled south again to Theodericus Pauli in Gorinchem. He added some marginalia of his own, at least on the first folio (f. $2 \mathrm{r}-2 \mathrm{v}$ ), and used the marginalia to interpolate his own Chronicle of Holland. At that point in time, it was returned to Leydis. This can be deduced from the marginalia, written in his hand, concerning the list of participants of the Third Crusade, which are absent from Pauli I and Pauli II. It is therefore likely that they were added after Pauli saw the manuscript.

After Leydis had added the names to his autograph, the manuscript was used by both the author of the Chronicon Hollandiae and by Leydis himself for his revised Chronicle of Holland. The author of the Chronicon Hollandiae received the manuscript and used it to compose his own text. By this time, an anonymous person would have already added the Latin translations of the opening chapters of the Chronicle of Gouda to the manuscript, which were then included in the Chronicon Hollandiae. Immediately below the last of these chapters in the Leydis I manuscript, a fictional story of Walachrijn is included, which Leydis copied from the Annals of Hainaut by Jacques of Guise (d. 1399) ${ }^{\text {II8 }}$ It appears to have been

118 London, BL, Cotton Vitellius E vi, f. 3v; A.J.F.X.P.E.S.P.A. Fortia d'Urban (ed.), Histoire de Hainaut, par Jacques de Guyse, traduite en français avec le texte Latin en regard et accompagnée de notes 2 (Paris/Bruxelles, 1826), pp. 246, 252254 (Lib. II, c. 64/66). 
written in the hand of Johannes a Leydis himself and the positioning lets us conclude is was written down after the translation of the Chronicle of Gouda. ${ }^{119}$ Walachrijn was an expelled duke of the Belgians, who supposedly went on to settle the island of Walcheren in Zeeland. This story is inserted by Leydis as one of the legendary origin myths in his second version of the Chronicle of Holland. ${ }^{120}$ After having been of so much assistance to others, the manuscript returned once more to the hands of Leydis for his own personal venture, Leydis II, the most substantial project he would take on.

The autograph manuscript of Leydis I was not the only codex to circulate within this community and within Holland. We have noted that both Pauli I and Pauli II were used by Johannes a Leydis for his second Chronicle of Holland. Theodericus Pauli drew from the work of Willem van Berchen and vice versa. The author of the Chronicon Hollandiae and Leydis most likely stood in contact with each other, as did Johan van Drongelen with both Leydis and Pauli. The discussed chronicles reached other historiographers in Holland as well. After Leydis' death, Willem Hermans (d. I510), a Canon Regular of Stein near Gouda, used the autograph of Leydis I for his Chronicle of Holland, preserved in a manuscript written at Egmond around $1514 .{ }^{121}$ Questions of whether or not Leydis I (in addition to Pauli I, Pauli II, and Leydis II) was used in the Divisiekroniek, attributed to Cornelius Aurelius (d. I53I), as Tilmans

119 The chapter written by Johannes a Leydis is placed directly beneath the preceding chapter, adopting the existing column layout of the text above.

120 J.D. Hintzen, 'Het Chronicon Comitum Hollandiae et Episcoporum Ultraiectensium. Joh. Gerbrandi a Leydis', Bijdragen voor Vaderlandsche Geschiedenis en Oudheidkunde, 5 (1922), I31-I43, here p. I35; C.P.H.M. Tilmans, 'Cornelius Aurelius en het ontstaan van de Bataafse mythe in de Hollandse geschiedschrijving (tot 1517)', in B. Ebels-Hoving, C.G. Santing and C.P.H.M. Tilmans (eds), Genoechlike ende lustige historiën. Laatmiddeleeuwse geschiedschrijuing in Nederland (Middeleeuwse studies en bronnen, 4) (Hilversum, 1987), pp. 191-213 (spec. 197); Sweertius, who edited the text of Leydis II in 1620, left out these origin myths (Lib. I, c. 2-13): Hintzen, 'Joh. Gerbrandi a Leydis', I3r; See also: Tilmans, 'Aurelius en de Bataafse mythe', p. 195, n. 15 .

${ }_{121}$ Compare 'ut quidam [...] circumvolutus est' (via Verkaik): London, BL, Cotton Vitellius E vi, f. II2v; Verkaik, De moord op graaf Floris $V$, 4I (n. 9I); For general information on the chronicle by Willem Hermans: C.P.H.M. Tilmans, 'De Hollandse kroniek van Willem Hermans ontdekt. Een Egmondse codex uit c. 1514', in Vis and Mostert (eds), Heiligenlevens, pp. 169-191 (spec. 169-170 and see also n. 56). 
suggested, should be re-examined using the new conclusions presented in this essay. ${ }^{122}$

It is to be expected that many more texts can be associated with the portrayed community of historiographers; not only other texts that belonged to the extensive oeuvre of Leydis, Pauli, and Berchen - we mainly addressed their Chronicles of Holland here - but also numerous other chronicles, adaptations, and interpolated copies, some of which have been barely studied at all. It would also be interesting to know how far, in a geographical sense, the exchange reached. There are indications that the exchange of these texts was not confined to the Northern Low Countries. As we have seen above, Leydis retrieved information about Walachrijn from the Annals of Hainaut by Jacques of Guise. This text mainly circulated in the Southern Low Countries, although a different part of this chronicle was translated into Middle Dutch and printed (probably) in Gouda in the County of Holland in $1486 .{ }^{123}$ The Croniken van der Duytscher Oirden also drew from many texts that were disseminated predominantly in the Southern Low Countries and the north of France. The case of the Croniken van der Duytscher Oirden even shows evidence of exchange that went well beyond the confinements of the Low Countries. Some of its sources, it appears, were brought from various locations in Europe, especially around the Baltic Sea, directly to Utrecht. Then, within years of the chronicle's conception, the text travelled back to circulate in Prussia and Livonia, only to return in a slightly adapted form to the Holy Roman Empire in or shortly after $1528 .^{124}$

Within the confinements of the Low Countries it could be of interest to look into the works of other prolific and contemporary historiographers, such as the enigmatic Master Hugues de Tolins or the canon regular Nicolaas Clopper. Nicolaas Clopper Jr., a son of a Brussels canon and canon himself at Mariënhage near Eindhoven in the Duchy of Brabant, is best known for a world chronicle, the Florarium temporum, which he

122 Tilmans, Historiography and humanism in Holland, pp. $166 \mathrm{ff}$.

${ }_{123}$ Meister Jacob van Valencijn, Dit is die jeeste van Julius Cesar (Gouda?, I 486) (ISTC nr. ixo0029500). It has been noted that Julius Caesar, in his dealings with the Belgians in this text, is a prefiguration of Maximilian of Austria: W. Keesman, 'Oorsprongsmythen als zelfuitlegging. Over achtergrond en betekenis van middeleeuwse verhalen rond Trojaanse stedenstichtingen', in H. Pleij (ed.), Op belofte van profijt. Stadsliteratuur en burgermoraal in de Nederlandse letterkunde van de middeleeuwen (Nederlandse literatuur en cultuur in de middeleeuwen, 4) (Amsterdam, 1991), pp. 262-279 (spec. 270).

124 Hirsch, 'Jüngere Hochmeisterchronik', I6. See also the forthcoming dissertation of Rombert Stapel. 
compiled from over two hundred sources. Two versions of the text exist; the first was completed in $1472 .{ }^{125}$ Much less is known of Hugues de Tolins, who was employed as historiographer by Duke Philip the Good of Burgundy in 1460-146I. His chronicles, none of which seem to have survived, were part of the library of Nicolaas Clopper who referred to him regularly. ${ }^{126}$ Together with Leydis, Pauli, Berchen, and the author(s)/ compiler(s) of the Middle Dutch Fasciculus temporum, perhaps (partly) linked to Drongelen, he belonged to a generation of historiographers in the Low Countries that wrote multiple histories of the duchies and counties being brought under Burgundian control. ${ }^{127}$

In the case of Nicolaas Clopper, we can establish a connection to the chronicles of Theodericus Pauli. One of the sources of his Florarium temporum is Beke. ${ }^{128}$ However, when, at the end of the chapter concerning Count Floris V of Holland, the description of the torture of his murderer Gerard van Velsen diverges from Beke, the remaining text itself is clearly related to the version of Pauli $I^{129}$ The structure and order of this section,

${ }_{125}$ In general: P.C. Boeren, Florarium temporum. Een wereldkroniek uit het jaar I472 (The Hague, 195I).

${ }^{126}$ The library of Mariënhage in Brabant, home of Nicolaas Clopper, once contained a chronicle of Holland that Tolins wrote, as well as his chronicles of France and Flanders. Clopper cited his Chronicle of France thirty times: Boeren, Florarium temporum, pp. 31, 52-53.

${ }_{127}$ Although the evidence is thin, Hugues de Tolins may have written a short Chronicle of Guelders that survived: 'Narrative Sources', NLo521; Regarding details of his life and work: G.P. Small, 'Of Burgundian dukes, counts, saints and kings (I4 C.E.-c. I520)', in D.A.J.D. Boulton and J.R. Veenstra (eds), The ideology of Burgundy. The Promotion of National Consciousness, ${ }_{13} 64-1565$ (Brill's Studies in Intellectual History, I45) (Leiden/Boston, 2006), pp. 15I-194.

128 Though in contrast to the Beke manuscript $(\mathrm{s})$ on which the chronicles by Leydis, Pauli, and Berchen were based, it was not a manuscript belonging to the A group. The section 'Hoc etenim [...] consimiliter obdormivit' is absent from the A group and therefore also absent from the chronicles of Leydis and Pauli: Bruch (ed.), Chronographia, c. 75 c. We have only been able to study the Munich manuscript that was finished in 1483: Munich, Bayerische Staatsbibliothek [further: BSB], Clm 10436, f. 255r. For Leydis c.s., see note 71.

129 'Atque idem [...] perpetuis temporibus': Munich, BSB, Clm 10436, f. 255r; Utrecht, UB, Ms. 1650, p. 396; Trier, SB, Ms. 1288/79, f. 103r-103v; The other chronicles give (various) aberrant readings: Bruch (ed.), Chronographia, c. $75 \mathrm{~d}$ (line 6-7); Van Leeuwen (ed.), Auctoris incerti Chronicon Tielense, 268; London, BL, Cotton Vitellius E vi, f. II2v; Tilmans, De Hollandse kroniek (thesis/ edition), c. 46; Sweertius (ed.), 'Chronicon Hollandiae comitum', p. 227; 
however, resembles Pauli II rather than the more elaborate account in Pauli I. ${ }^{130}$

Elsewhere, pieces of text correspond to Pauli's Chronicon universale (c. I480-1490) ${ }^{131}$ and the Chronicon Tielense - an anonymous world chronicle written between 1450 and 1455 in the Duchy of Guelders, which was also largely based on Beke. ${ }^{132}$ Müller claimed that the Chronicle of Holland by Leydis (i.e., Leydis II) was also used as a source for the Florarium temporum, although Boeren later rejected this. ${ }^{133}$ Neither Pauli nor Leydis were explicitly mentioned by Clopper in his list of sources, but they would not have been the only contemporary texts Clopper failed to mention. ${ }^{134}$ It is equally uncertain whether the Florarium temporum used the Chronicles of Guelders by Berchen or only shared some sources. ${ }^{135}$ The relationship of the Florarium temporum to these authors should be studied further. This is all the more interesting since Clopper himself seems to have been part of another, similar historiographers' circle in Brabant, associated with the Congregation of Windesheim. ${ }^{136}$

Another example is the addition that Andreas van Cuijk, Bishop of Utrecht from II 8 to 1139, was a 'Leodiensis prepositus' prior to his election. Note that this addition can only be found in Pauli I and the Florarium temporum, but for instance - strangely enough - not in Pauli II: Munich, BSB, Clm I0436, f. 202r; Utrecht, UB, Ms. 1650, p. I57; Trier, SB, Ms. I288/79, f. 53 r.

130 Trier, SB, Ms. I288/79, f. I03r-I03v.

131 Boeren, Florarium temporum, 55-56; Munich, BSB, Clm 10436, f. 826v.

132 Boeren, Florarium temporum, 26 (n. 60); Compare 'Anno Domini [...] edificari fecit': Munich, BSB, Clm 10436, f. 212r; Van Leeuwen (ed.), Auctoris incerti Chronicon Tielense, I40; A similar, but more elaborate version of events can be found in Berchen's Chronicle of Guelders: Sloet van de Beele (ed.), De nobili principatu Gelrie, pp. 4, 36. The passage is absent from all other chronicles that we examined.

133 K.E.H. Müller, Das Magnum Chronicon Belgicum und die in demselben erhaltenen Quellen. Ein Beitrag zur Historiographie des 15. Jahrhunderts (Berlin, I888) pp. 26-27; Romein, Noord-Nederlandsche geschiedschrijving, p. 202; Boeren, Florarium temporum, pp. 45-46.

134 Vermassen, 'De Nova historia ducum Brabantiae', 212; this practice is remarkably similar to that of Cornelius Aurelius who also failed to explicitly mention contemporary authors he consulted: Tilmans, Historiography and Humanism in Holland, p. 192.

135 Boeren, Florarium temporum, pp. 37-38.

136 This circle is based on a collection of links between authors such as Nicolaas Clopper Jr., Henricus de Merica, Johannes Meerhout, the anonymous author of the Magnum Chronicon Belgicum, Johannes Gielemans, and Petrus de 


\section{Conclusions}

It is no exaggeration to state that Pauli, Berchen, and Leydis alone shaped much of our current image of the late medieval historiography in the Northern Low Countries. The identification of Leydis, Pauli, Berchen, and Drongelen at the nucleus of a community of historiographers opens our eyes to certain developments in history writing. By studying them as a group, the attention is drawn to a list of characteristics that they all share. This community of writers all have clerical backgrounds, but write in urban environments. They all seem to write from a deep interest in history and genealogy, which prompts them to rewrite previous work and continue to write on a wide array of counties, duchies, and families. Although the vernacular was widely used by the second half of the fifteenth century, these authors preferred to write in Latin. These features of history writing can only be recognized and subsequently studied because of the perspective of interactions between them. Identifying collective authorship opens up new questions of audience, patronage, ideas, and common characteristics.

What becomes abundantly clear is that history writing in the Low Countries was certainly not a lonely profession. Rather, new texts were constantly and very rapidly exchanged to incite fresh views on the area's history. This process was much more than just collecting new information. The authors did not blindly copy each other's works into their own, but interacted with each other and made choices on what to include and where. They continually adapted their material until they were happy with their results - or, more cynically, until they died. Therefore, the extant manuscripts should be regarded as a physical relic of a historiographical dialogue. This dialogue will certainly not have been limited itself to just three history writing enthusiasts, Leydis, Pauli and Berchen. Rather, it will have included other less well-known readers and writers as well; people who were part of a lively and growing group interested in (and capable of) history writing in the fifteenth-century Low Countries. How far this group extended exactly is, as of yet, difficult to tell and attempts should

Thimo: J. Tigelaar, Brabants historie ontvouwd. Die alder excellenste cronyke van Brabant en het Brabantse geschiedbeeld anno I5oo (Middeleeuwse studies en bronnen, 98) (Hilversum, 2006), pp. 164-166; V. Vermassen, 'Le Florarium sanctorum de Nicolaus Clopper jr et le Martyrologe Brabançon de Pierre de Thimo. Deux martyrologes perdus, deux hagiographes brabançons méconnus', Analecta Bollandiana, 126 (2008), 119-150; Vermassen, 'De Nova historia ducum Brabantiae'. 
be made to identify similar textual communities in other times and areas, such as the Southern Low Countries or Germany.

This article shows that in order to examine the relationships between contemporary medieval authors, in those typical cases when direct evidence such as correspondence is lacking, it is fruitful to examine the exact affiliation of their texts. Unfortunately, this approach is both time- and energy-consuming and depends entirely on the availability of editions, transcripts, or, at the very least, accessible digital copies. When texts are so closely intertwined, and often based on similar sources, it is difficult to draw precise conclusions about their relationships. The only solution is to lay the whole range of texts and manuscripts that one expects to be affiliated side-by-side and compare them. ${ }^{137}$ Hopefully, digital editions and transcripts will make comparisons easier in the future and will make larger overviews possible.

By becoming aware of the idea of history writing as a possible collective effort, new light can be shed on characteristics of medieval authors and their work, as well as on concepts around textual communities. Therefore, this study is an incentive to review our methods of studying history writing, which is now often focused on one work or one author at the time. The production of history writing in Holland was not limited to individual authors. The cases set out in this article show that a group of (mostly) urban clergy was interested, financially capable, and informed enough to write a large collection of history works on the Low Countries without patronage from the elite. This calls for further study of historiography in the late medieval Low Countries from the perspective of collaborative authorship. Recognition of the possibility of medieval collaborative writing will cause more of such textual communities to be uncovered, which will change the traditional perception of history writing in Holland and the Low Countries.

${ }_{137}$ For instance, we would have liked to have included Pauli's Chronicon universale and Liberbellorum dei in our study, two texts that certainly contain corresponding passages, but we were not able to obtain transcripts or reproductions of the texts and manuscripts and had to rely on secondary literature. 
